\title{
Pathways to achieve a set of ambitious global sustainability objectives by 2050: Explorations using the IMAGE integrated assessment model
}

\author{
Detlef P. van Vuuren ${ }^{\mathrm{a}, \mathrm{b}, *}$, Marcel Kok ${ }^{\mathrm{a}}$, Paul L. Lucas ${ }^{\mathrm{a}}$, Anne Gerdien Prins ${ }^{\mathrm{a}}$, Rob Alkemade ${ }^{\mathrm{a}, \mathrm{c}}$, \\ Maurits van den Berg a,d, Lex Bouwman ${ }^{\mathrm{a}, \mathrm{b}}$, Stefan van der Esch ${ }^{\mathrm{a}}$, Michel Jeuken ${ }^{\mathrm{e}}$, \\ Tom Kram ${ }^{\mathrm{a}}$, Elke Stehfest ${ }^{\mathrm{a}}$ \\ a PBL Netherlands Environmental Assessment Agency, Bilthoven, The Netherlands \\ ${ }^{\mathrm{b}}$ Utrecht University, Utrecht, The Netherlands \\ c Wageningen University and Research Centre (WUR), Wageningen, The Netherlands \\ d EC Joint Research Centre (JRC-IES), Ispra, Italy \\ e Deltares, Delft, The Netherlands
}

\section{A R T I C L E I N F O}

\section{Article history:}

Received 25 August 2014

Received in revised form 21 February 2015

Accepted 2 March 2015

Available online 31 March 2015

\section{Keywords:}

Integrated assessment

Modelling

Sustainable development

Global change

\begin{abstract}
A B S T R A C T
In 2012, governments worldwide renewed their commitments to a more sustainable development that would eradicate poverty, halt climate change and conserve ecosystems, and initiated a process to create a long-term vision by formulating Sustainable Development Goals (SDGs). Although progress in achieving a more sustainable development has been made in some areas, overall, actions have not been able to bend the trend in critical areas (including those related to the so-called food-water-energy nexus). Here, we analyze how different combinations of technological measures and behavioral changes could contribute to achieving a set of sustainability objectives, taking into account the interlinkages between them. The objectives include eradicating hunger, providing universal access to modern energy, preventing dangerous climate change, conserving biodiversity and controlling air pollution. The analysis identifies different pathways that achieve these objectives simultaneously, but they all require substantial transformations in the energy and food systems, that go far beyond historic progress and currently formulated policies. The analysis also shows synergies and trade-offs between achieving the different objectives, concluding that achieving them requires a comprehensive approach. The scenario analysis does not point at a fundamental trade-off between the objectives related to poverty eradication and those related to environmental sustainability. The different pathways of achieving the set of long-term objectives and their implications for short-term action can contribute to building a comprehensive strategy to meet the SDGs by proposing near-term actions.
\end{abstract}

(c) 2015 Elsevier Inc. All rights reserved.

\section{Introduction}

In June 2012, world leaders, policy makers, NGO representatives and scientists came together at the United Nations Conference on Sustainable Development (UNCSD) in Rio de Janeiro (Rio +20 ). One purpose of this conference was to evaluate progress in moving towards sustainable development.

\footnotetext{
* Corresponding author at: PBL Netherlands Environmental Assessment Agency PO BOX 3033720 AH Bilthoven, The Netherlands. Tel.: + 31611956484.
}

Twenty years earlier, also in Rio de Janeiro, the UNCED conference (the United Nations Conference on Environment and Development) adopted the so-called Rio Declaration on Environment and Development (UNCED, 1992). In this declaration, countries worldwide agreed on a set of key ambitions in achieving sustainable development, including environmental protection (Principle 4) and poverty eradication (Principle 5), while also three conventions related to responding to climate change, biodiversity loss and desertification were adopted. Since then, many more related sustainable development goals have 
been agreed on internationally, including freeing people from extreme poverty and multiple deprivations (Millennium Development Goals, UN, 2000), climate targets (UNFCCC, 2010) and the objective to halt biodiversity loss by 2020 after a failure to realize this goal by 2010 (CBD, 2010). Documents in preparation of the Rio +20 conference, showed that despite some progress, actions have not been able to bend the trend for critical issues such as access to sufficient food and modern forms of energy, preventing dangerous climate change, conserving biodiversity and controlling air pollution (UNEP, 2012). Therefore, the Rio +20 conference also intended to secure renewed political commitment for sustainable development and agree upon a further set of actions.

By now it can be concluded that while the Rio +20 conference reiterated the ambition to achieve sustainable development, countries did not really manage to agree to additional actions in a strong and meaningful way (Bernstein, 2013; GEGP, 2012; Hanrahan, 2012). Arguably, the conference's most important decision was to develop a set of socalled Sustainable Development Goals (SDGs) for 'pursuing focused and coherent action on sustainable development' (UN, 2012). The SDGs should formulate a universal agenda applicable to all countries, integrating the social, environmental and economic dimensions of sustainability. The process to formulate SDGs has merged with the process to formulate the post-2015 development agenda, the new development agenda that should succeed the Millennium Development Goals (MDGs) when they expire in 2015, to address both poverty eradication and sustainable development. The MDGs had a similar role earlier, although focusing primarily on poverty eradication, promoting action to achieve a set of human development-related targets. Furthermore, similar to the MDGs, the SDGs should be accompanied by targets and indicators to measure progress towards the achievement of these goals (Bernstein, 2013; Evans and Steven, 2012; Ivanova, 2013).

The process of selecting a set of SDGs is now well underway (although it has been argued that the lack of a consistent vision has complicated the process of developing SDGs (Bernstein, 2013)). Ideally, the SDGs strike a balance between near-term action and long-term ambition. Studies that depict pathways that relate near-term actions and a long-term vision could help implementing the SDGs by 1) providing a link between a longterm inspirational vision to a medium-term set of sustainable development goals (say by 2025 or 2030), 2) showing what efforts would be needed to realize the goals and 3) providing information on the inter-linkages (synergies and trade-offs) between the achievement of the goals. The first two points are particularly important given the separation of many international policies between long-term ambitions and short-term actions (Klein, 2013; Riahi et al., 2015). The current paper describes an analysis that looks into the question how different pathways (or scenarios - see Methods Section) could evolve that aim at achieving a long-term sustainability vision. We concentrate on the sustainable developed challenges related to the energy-food-water nexus which lies at the hearth of the world's sustainability problems (see for instance recent international assessments such as UNEP's Global Environmental Outlook and the IPCC reports). The pathways in this paper fully address these three key areas of sustainability and their interactions - and as such form an unique contribution to the existing literature on response strategies and scenario analysis: integrated assessment models did not analyse before such scenarios addressing such a wide set of issues. These pathways are designed to all achieve the same set of targets in 2050 related to the energy-food-water nexus, but by different (contrasting) combinations of technological measures and consumption changes. The key questions of the paper are:

- How would different pathways evolve aimed at achieving a broad set of sustainable development targets in 2050 ?

- What do such pathways tell us on the level of (near and medium-term) action consistent with achieving these targets?

From earlier environmental assessments (e.g. MA, 2005; UNEP, 2012), the conclusion can be drawn that (closely connected) clusters of issues (the so-called nexus) play a critical role in the sustainable development debate: 1) ensuring sufficient food supply while conserving biodiversity, and 2) ensuring a modern energy access for all while limiting global climate change and air pollution. We have organized the discussion in these two clusters, but it should be noted that our analysis is in fact integrated, and analyzes how goals can be achieved simultaneously. The paper also briefly discusses the relations with measures implemented in the two focus areas with water scarcity, imbalances in the Earth's nutrient cycles, and human health loss. In our analysis, we account for the technical and physical limitations that play a role in achieving long-term targets. At the same time, we leave the question whether achieving the set of targets is feasible from a political perspective aside to provide full insight into potential options. An essential aspect of the sustainability challenge is that it covers a very wide range of related issues. Therefore, it is not always possible to present the underlying details of our analysis, for which we refer at places to earlier, more detailed, work and a more extensive report (PBL, 2012).

The structure of the paper is as follows: First, in Section 2 we discuss the methods that have been applied in this paper. Second, in Section 3 we discuss the main scenarios and their results for land-use and related issues and energy use and related issues. Finally, in Section 4 we draw conclusions.

\section{Methods}

\subsection{Modeling approach}

In the study, we applied a model-based scenario approach in which scenarios are used to analyze what is needed to achieve a set of 2050 sustainability objectives. ${ }^{1}$ Often, scenarios are designed to be forward-looking: i.e. explore how the future could evolve on the basis of a preset storyline (a set of assumptions), also referred to as explorative scenarios (van Vuuren et al., 2012a). The purpose of the exercise, here, in contrast, is to explore the characteristics of scenarios that are designed to achieve a set of future objectives. Such scenario approach is often referred to as normative scenarios or as backcasting. It should be noted that in analytical sense, the

\footnotetext{
1 In order to avoid confusion with the SDGs, that tend to be formulated for a shorter time frame, we avoid the word goals for 2050 but instead stick to the words targets and objectives.
} 
difference between these different scenario approaches is not that large and various intermediate approaches exists.

A second issue with regard to methods, is that we use the word pathway here as a somewhat more generic description of ways to achieve specific objectives in the future. In contrast, the word scenario refers to a more quantitative description of how the future may unfold, based on an internally consistent (i.e. model-based) set of assumptions. The difference is, however, not always clear-cut.

The modeling framework used for this paper, the IMAGE integrated assessment model (Bouwman et al., 2006; Stehfest et al., 2014), takes into account, as much as possible, the limitations in terms of physical and economic feasibility (e.g. potential for improving crop yields and the capital turnover rate in the energy system). Political and societal constraints on feasibility have not been explicitly taken into account for the development of pathways. Instead, we have used the scenario outcomes to discuss some of the policy implications.

The method used consists of 3 key steps as depicted in Fig. 1:

1. Selecting a set of key sustainable development objectives for 2050 , consistent with a long-term vision on sustainable development (see Section 2.3)

2. Developing a so-called Trend scenario that starts from historical trends and looks into future developments without the introduction of new policies (see Section 2.4)

3. Developing a set of three contrasting alternative scenarios (Challenge Scenarios or Sustainable Development Scenarios) aimed at achieving the set of sustainable development objectives, explicitly describing the measures taken in these scenarios (see Section 2.5)

This analysis clearly goes beyond earlier model-based scenario assessments in this area. First, earlier assessments have mostly focused on separate issues (e.g. on climate), whereas, in this paper, we consider the challenge of achieving a comprehensive set of objectives, within the same time frame, for different issues. This allows us to look at the important linkages between the issues. Second, also the use of comprehensive analysis of the nexus related issues provides an important new element compared to existing literature. Finally, the use of scenarios defined on the basis of 2050 goals (normative scenarios) is relatively uncommon. It should be noted that in our analysis we focus on the type of measures needed to respond to the nexus related challenges. For many of these, it is not easy to estimate costs (e.g. dietary change). Therefore, instead of estimating costs, we try aim to describe the associated efforts, and synergies and trade-offs of the different strategies in more physical indicators.

\subsection{IMAGE integrated assessment model}

The IMAGE integrated assessment model looks into global environmental developments based on different assumptions with regard to socio-economic development and policy (Bouwman et al., 2006). The model consists of several coupled models that describe the energy and land use system, and also represents the natural earth system, such as climate and natural vegetation. Most of the subcomponents of IMAGE are simulation models, i.e. a set of rules determines the future developments of, for instance, the energy system and land use. The human systems are described in IMAGE at the level of 24-26 regions. The natural system is described mostly on a $0.5 \times 0.5$ grid. The strength of the model is that it is able to connect various sustainable development topics.

In the energy system, different technologies compete for a share in investment flows on the basis of their relative costs. The focus of the model is on describing long-term dynamics. Long-term decisions in the energy system are assumed to be governed by the relative costs of various technologies. These long-term costs are assumed to be determined by two processes: depletion and technology dynamics, which in turn are driven by (cumulative) production. In the land use model,

\section{Backcasting analysis, working back from a sustainable end point to determine actions for today}

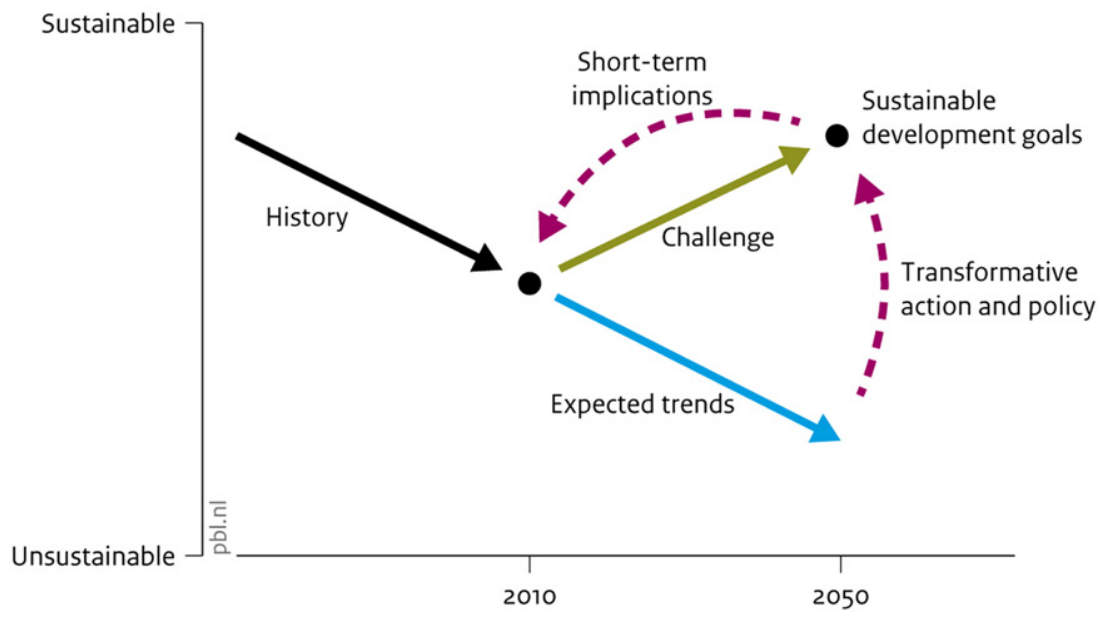

Fig. 1. Main study design. First, a set of Sustainable development goals has been derived from existing international treaties. The Trend Scenario explores expected trends. The Challenge Scenarios or Sustainable Development Scenarios in contrast explore the transformative action and policies that are needed to meet these goals compared to the Trend Scenario. Finally, the study looked into the implication for decisions in the short-term. 
key inputs are the demand for production of food, feed, animal products and bio-energy. The demand for the first three products are in most IMAGE studies (including this one) designed using a link with the general equilibrium model MAGNET that assigns agricultural production to regions based on relative production costs, based on biophysical information on land-supply per region in the IMAGE model (Bouwman et al., 2006). This means that information is exchanged between these models: first the impact of local climate and soil conditions on yields determine the land-supply curve. Next, the MAGNET calculations determine regional demand for agricultural products, trade, production levels - but also the impact of investments into technology and management in response to land scarcity. Demand for bio-energy crops (mostly second generation) comes from the energy model and is only allowed on land not used for food production. Subsequently, the required land use is translated into a $0.5 \times 0.5$ degree land use map by a set of allocation rules, including a preference for high yield grid cells, the proximity of other agricultural and urban areas, excluding protected areas (nature reserves) and built-up areas. Expansion of agricultural area will lead to a loss of natural area, but also (depending on the ecosystem that is converted) additional $\mathrm{CO}_{2}$ emissions from land-use change. The iteration between the core IMAGE model and MAGNET is performed in this study is performed for the baseline and policy scenarios.

The IMAGE model is coupled for the analysis described here to the GLOBIO and GISMO model. GLOBIO assesses the changes in global biodiversity by comparing the future situation with the natural situation (thus measuring ecosystem intactness) with respect to 1) size of the ecosystems and 2) its quality (as estimated on the basis of pressure factors). The product of these two factors is referred to as the Mean Species Abundance index (MSA) (Alkemade et al., 2009). For pressures, the GLOBIO model covers climate change, nitrogen deposition, infrastructure development/disturbance (driven mostly by income), fragmentation, and forestry and extraction activities. To determine changes in human development in relation to the global environmental changes calculated in IMAGE, the GISMO model is used (Hilderink and Lucas, 2008). This model is used here to determine hunger (prevalence of undernourishment and child underweight), access to drinking water and sanitation and impacts on child mortality of hunger and lack of access to safe drinking, basic sanitation and modern energy sources. Key inputs from the IMAGE model are food supply, residential energy use, air pollution and climate change. In GISMO, this is combined with assumptions on the distribution in supply, relationships between environmental factors, income levels and health and demographic factors.

\subsection{Sustainable development objectives}

As indicated in the introduction, the goal of this study is to analyze pathways for achieving a broad set of sustainable development objectives and targets that together provide a vision for 2050. These objectives are connected to the main principles of the Rio Declaration, in particular Principle 5 (eradicate poverty) and Principle 6 (conserve the Earth's ecosystem), and focuses on the two clusters: food and biodiversity loss as well as energy use and climate change. We have defined the long-term objectives mostly for 2050 (sometimes
2030): a period that is nearby enough to be relevant to today's policy decisions and far enough in the future to make a noticeable difference.

The objectives selected for the study and the main sources for these are indicated in Table 1 . In the selection, we concentrated on objectives related to the key areas of sustainable development and the land-energy nexus as indicated in several environmental studies, i.e. provision of energy and food, mitigating climate change, providing clean air and reducing the loss of biodiversity. In Table 1, we specifically use the first five objectives as normative targets for the scenarios. The other targets are still used to monitor progress against to identify synergies and trade-offs. The set of objectives and targets analyzed here is based on existing international agreements on environmental and development topics, extended with proposed objectives and targets from high-level UN advisory groups and insights from the scientific literature. As such the set can be regarded as a proxy for the SDGs currently discussed in the UN system. For biodiversity and energy related targets, a more in depth discussion can be found elsewhere (Lucas et al., 2014; Nilsson et al., 2013). It should also be noted that for several other areas (water and nitrogen) clear, feasible, quantitative objectives have not been agreed upon internationally. ${ }^{2}$

\subsection{Scenario assumptions}

\subsubsection{Trend scenario}

The starting point of our analysis is the so-called Trend scenario, a description of possible developments assuming that no new policies are introduced in order to achieve sustainable development targets. In this scenario, we assume that the world population continues to grow from around 7 billion people in 2010 to 9 billion by 2050 (UN, 2008). This growth mostly occurs in sub-Saharan Africa and South Asia. At the same time, the projection for economic growth (based on the OECD Environmental Outlook to 2050 (OECD, 2012)) shows a further increase in per-capita GDP in all world regions. Most economic growth is expected in developing countries. Towards 2040, the highest growth rates are projected for Asia. After 2040, the highest per capita growth rates are projected for Africa, although it will remain the continent with the lowest per capita income levels. In terms of policies, the scenario is also a continuation of current trends, i.e. some improvement in legislation related to environmental protection and development, but insufficient to bend the existing trends.

\subsubsection{Challenge Scenarios}

The three Challenge Scenarios are derived from the Trend scenario. In all three alternative scenarios we induce changes in policies, lifestyle and technology development so that the set of sustainable development objectives is met. They, however, differ in the type of measures introduced to meet these objectives: i.e. their emphasis on changing consumption

\footnotetext{
2 One may note that for some environmental issues indicated in Table 1 , Rockstrom et al. (2009) and more recently Steffen et al. (2015) suggested quantified 'planetary boundaries'. The proposed planetary boundaries are often a little more stringent than the targets looked into here, implying that even if the proposed set of objectives would be achieved, the world could still be exposed to a level of global environmental change exceeding the conditions observed during the Holoscene (the criteria used to design the planetary boundary indicator set).
} 
Table 1

Main objectives and targets for the analysis.

\begin{tabular}{|c|c|c|c|}
\hline Category & Objective & Targets & Source/rationale \\
\hline Food & Eradicate hunger & $\begin{array}{l}\text { Halve, between } 1990 \text { and } 2015 \text {, the proportion of } \\
\text { people who suffer from hunger; halve this again } \\
\text { by 2030, and fully eradicate hunger by 2050; }\end{array}$ & $\begin{array}{l}\text { The target to eradicate hunger was derived } \\
\text { from MDG } 1 \text { and extrapolated to } \\
2050 \text { based on overall MDG ambition to } \\
\text { eradicate hunger (UN, 2000) }\end{array}$ \\
\hline Biodiversity & $\begin{array}{l}\text { By } 2050 \text {, biodiversity is valued, } \\
\text { conserved, } \\
\text { restored and wisely used, maintaining } \\
\text { ecosystem services, sustaining a healthy } \\
\text { planet and delivering benefits essential } \\
\text { for all people }\end{array}$ & $\begin{array}{l}\text { Halve the rate of loss of biodiversity by } 2020 \\
\text { and maintain biodiversity at the } 2020 / 2030 \text { level } \\
\text { by } 2050 \text { (depending on region). } \\
\text { By } 2020 \text {, at least } 17 \% \text { of terrestrial and inland } \\
\text { water areas are conserved effectively }\end{array}$ & $\begin{array}{l}\text { The analysed biodiversity target was derived } \\
\text { from the CBD's long-term vision to conserve, value, } \\
\text { restore and wisely use biodiversity as well as the } \\
\text { CBD's Aichi target } 5 \text { that aims to at least halve, and } \\
\text { where feasible bring close to zero, the rate of loss } \\
\text { of all natural habitats by } 2020 \text {. } \\
\text { (CBD, 2010). }\end{array}$ \\
\hline Energy & $\begin{array}{l}\text { Ensure universal access to modern } \\
\text { energy }\end{array}$ & $\begin{array}{l}\text { Achieve universal access to electricity and modern } \\
\text { cooking fuels by 2030; }\end{array}$ & $\begin{array}{l}\text { Proposed goal UNSG and AGECC } \\
\text { (AGECC, 2010); JPoI-Para 9(a) }\end{array}$ \\
\hline Climate & $\begin{array}{l}\text { Prevent dangerous anthropogenic } \\
\text { interference with the climate system }\end{array}$ & $\begin{array}{l}\text { Avoid an increase of global mean temperature } \\
\text { above } 2^{\circ} \mathrm{C} \text {; keep atmospheric greenhouse gas } \\
\text { concentrations below } 450 \mathrm{ppm} \mathrm{CO2} \mathrm{equivalent;}\end{array}$ & $\begin{array}{l}\text { UNFCCC (1992) - Art. 2; Cancun agreement } \\
\text { (UNFCCC, 2010) }\end{array}$ \\
\hline Air pollution & $\begin{array}{l}\text { Improve air quality in their cities in } \\
\text { order to protect people's health }\end{array}$ & $\begin{array}{l}\text { Keep annual PM } 2.5 \text { concentrations below } \\
35 \mu \mathrm{g} / \mathrm{m} 3 \text { by } 2030\end{array}$ & (WHO, 2005) \\
\hline $\begin{array}{l}\text { Water } \\
\text { scarcity }\end{array}$ & Ensure sustainable use of water resources & $\begin{array}{l}\text { Ensure full access to safe drinking water by } 2050 \\
\text { and reduce the level of people exposed to water } \\
\text { scarcity }\end{array}$ & $\begin{array}{l}\text { The JPoI Paragraph 26(c) calls for an 'efficient } \\
\text { and well-balanced use of freshwater resources' } \\
\text { as well as for 'safeguarding drinking water } \\
\text { quality'. }\end{array}$ \\
\hline N-cycle & $\begin{array}{l}\text { Avoid acidification of terrestrial } \\
\text { ecosystems } \\
\text { and eutrophication of coastal and } \\
\text { freshwater systems }\end{array}$ & $\begin{array}{l}\text { Reduce N/P use where possible (but without } \\
\text { harming } \\
\text { the ability of the agricultural system to meet the } \\
\text { hunger target) }\end{array}$ & \\
\hline Human health & Reduce environmental health threats & $\begin{array}{l}\text { Reduce environmental health deaths such as those } \\
\text { related to lack of access to food, safe drinking water } \\
\text { and modern energy (for instance resulting from } \\
\text { indoor air pollution and hunger). }\end{array}$ & $\begin{array}{l}\text { The JPoI Paragraph } 7(f) \text { calls to 'reduce } \\
\text { environmental health threats, taking into } \\
\text { account the special needs of children'. }\end{array}$ \\
\hline
\end{tabular}

patterns, the role of large-scale technology change and the focus on global versus local approaches (see Table 2; for a detailed description of the storylines and descriptions see also (PBL, 2012)). As such, the Challenge Scenarios address the question of the flexibility in response options. Clearly, it is not meant to imply that these are the preferred development trajectories, nor that they are the only pathways possible. In the global technology scenario, we assume that sustainable development is pursued mainly by large scale technology solutions, e.g. responses that are similar in different regions. Global markets drive the implementation of these responses. In the decentralized solutions scenario, in contrast, we look more for decentralized responses, mostly consisting of technologies that can be implemented on a smaller scale and better combined with an emphasis on regional diversity. The same applies for changes in governance structures. Finally, the consumption change scenario, starts from implementing a set of behavioral changes that reduce consumption levels (e.g. diets).

In Tables 3 and 4 we have more specifically indicated the assumptions for each of the Challenge Scenarios for land- use and biodiversity and energy and climate, respectively. We derived the measures and the quantitative assumptions for implementation from the storylines and the literature. Regarding the ambition of the policies, we looked into studies on ambitious but feasible implementation. Some examples include rapid efficiency improvement in line with underlying publications on energy efficiency, the scope for carbon storage, the potential for large-scale sustainable bio-energy and dietary change. For each scenario, first key assumptions were implemented in line with the storyline. If a gap remained in each scenario in reaching the sustainability objectives than these were met in an iterative process by 1) increasing the carbon tax for climate change (stimulating a range of measures), 2) introduction efficient stoves for access to modern energy and 3) further increasing agricultural yields (for protecting biodiversity). As indicated in Section 2.2, landuse policies were iterated between the physical land-use model of IMAGE and the agro-economic model MAGNET. It should be noted that we have only allowed bio-energy production under strict sustainability criteria: i.e. only second

Table 2

Main assumptions in the different sustainable development (Challenge) scenarios.

\begin{tabular}{ll}
\hline Scenario & Main assumptions \\
\hline Global technology & $\begin{array}{l}\text { Achieves the } 2050 \text { targets, with a focus on large-scale technologically optimal solutions, such as intensive agriculture and fossil } \\
\text { fuel use with carbon-capture-and-storage. The pathway also emphasizes a high level of international coordination, for instance } \\
\text { through trade liberalization. } \\
\text { Decentralised solutions }\end{array}$ \\
$\begin{array}{l}\text { Achieves the } 2050 \text { targets, but with a focus on decentralized solutions, such as local energy production, agriculture that is } \\
\text { interwoven with natural corridors and national policies that regulate equitable access to food. } \\
\text { Consumption change }\end{array}$ & $\begin{array}{l}\text { Achieves the } 2050 \text { targets, with a focus on changes in human consumption patterns, most notably by limiting meat intake } \\
\text { per capita, reducing waste generation and the choice for less energy-intensive lifestyles. }\end{array}$ \\
\hline
\end{tabular}


Table 3

Key assumptions for measures introduced in each sustainable development (Challenge)scenarios - land-use and biodiversity.

\begin{tabular}{|c|c|c|c|c|}
\hline & Trend & Global technology & Dencentralised solutions & Consumption change \\
\hline Access to food & $\begin{array}{l}\text { Trends driven by historically } \\
\text { observed relationships with } \\
\text { income }\end{array}$ & Trend & $\begin{array}{l}\text { Inequality in the distribution of } \\
\text { global per capita consumption } \\
\text { rates reduced so that all people } \\
\text { are above the minimum } \\
\text { consumption level in } 2050\end{array}$ & $\begin{array}{l}\text { Inequality in the distribution of } \\
\text { global per capita consumption } \\
\text { rates reduced so that all people } \\
\text { are above the minimum } \\
\text { consumption level in } 2050\end{array}$ \\
\hline Trade & $\begin{array}{l}\text { No further liberalization } \\
\text { beyond current policies }\end{array}$ & $\begin{array}{l}\text { Full liberalization of trade in } \\
\text { agricultural products }\end{array}$ & Trend & Trend \\
\hline Consumption & $\begin{array}{l}\text { Income driven consumption } \\
\text { trends }\end{array}$ & Trend & Trend & $\begin{array}{l}\text { Meat consumption levels of at a } \\
\text { twice the level suggested for a } \\
\text { healthy diet (Stehfest et al., 2009) }\end{array}$ \\
\hline $\begin{array}{l}\text { Supply chain } \\
\text { waste and losses }\end{array}$ & At historical values & Trend & Trend & $\begin{array}{l}\text { Waste and losses are halved (to 15\% } \\
\text { of production) (IMECHE, 2012) }\end{array}$ \\
\hline $\begin{array}{l}\text { Agriculture } \\
\text { productivity }\end{array}$ & $\begin{array}{l}\text { Based on trends in FAO } \\
\text { scenario (FAO, 2006) }\end{array}$ & $\begin{array}{l}\text { In all regions, yield } \\
\text { improvement } 30 \% \text { higher for } \\
\text { crops and } 15 \% \text { higher for } \\
\text { livestock than trend scenario }\end{array}$ & $\begin{array}{l}\text { In all regions, yield improvement } \\
20 \% \text { higher for crops and } 15 \% \\
\text { higher for livestock than trend } \\
\text { scenario, only in those areas that } \\
\text { are least vulnerable for biodiversity } \\
\text { loss }\end{array}$ & $\begin{array}{l}\text { In all regions, } 15 \% \text { improvement } \\
\text { in crop yields. }\end{array}$ \\
\hline Land planning & $\begin{array}{l}\text { Default rules in IMAGE } \\
\text { model }\end{array}$ & $\begin{array}{l}\text { Expansion of agriculture areas } \\
\text { close to existing areas in order } \\
\text { to retain highly distinct land } \\
\text { functions }\end{array}$ & $\begin{array}{l}\text { Production areas shared with } \\
\text { nature elements to reinforce } \\
\text { ecological network. Keep at least 30\% } \\
\text { of landscape as nature elements. }\end{array}$ & Trend \\
\hline $\begin{array}{l}\text { Protected } \\
\text { areas }\end{array}$ & $\begin{array}{l}\text { No change in protected } \\
\text { areas }\end{array}$ & $\begin{array}{l}17 \% \text { of each of } 7 \text { biodiversity } \\
\text { realms protected. Protected } \\
\text { areas far from agriculture. }\end{array}$ & 17 of the 779 ecoregions protected. & $\begin{array}{l}17 \% \text { of the } 65 \text { realm/biomes } \\
\text { protected. }\end{array}$ \\
\hline Forestry & $\begin{array}{l}\text { Wood demand increases } \\
\text { driven by increase in income }\end{array}$ & $\begin{array}{l}\text { Forest plantations supply } 50 \% \\
\text { of timber demand. Almost all } \\
\text { selective logging. }\end{array}$ & $\begin{array}{l}\text { Forest plantations supply } 50 \% \text { of } \\
\text { timber demand. Almost all selective } \\
\text { logging. }\end{array}$ & $\begin{array}{l}\text { Forest plantations supply } 50 \% \text { of } \\
\text { timber demand. Almost all } \\
\text { selective logging. }\end{array}$ \\
\hline Infrastructure & $\begin{array}{l}\text { Impact of infrastructure on } \\
\text { biodiversity increases based } \\
\text { on historic correlations. }\end{array}$ & Trend & $\begin{array}{l}\text { Slower expansion of infrastructure } \\
\text { ( } 2050 \text { values equal to } 2030 \text { values } \\
\text { of trend) }\end{array}$ & $\begin{array}{l}\text { Slower expansion of infrastructure } \\
\text { ( } 2050 \text { values equal to } 2030 \text { values } \\
\text { of trend) }\end{array}$ \\
\hline
\end{tabular}

generation bio-energy, only allowing production on abandoned agricultural land or part of natural grassland and excluding nature areas, water scarce areas and severely degraded areas. While these criteria can be easily introduced in the model, implementation in the real world will not be as straightforward. Policies implementing sustainability criteria have been proposed for the direct land used for bio-energy production, but the land-use changes for other crops (e.g. food) induced by bio-energy production will be more difficult to control - and may require more comprehensive strategies (e.g. implementing also sustainability criteria for food production). Finally, for air pollution, in the Challenge Scenarios,

Table 4

Key assumptions for measures introduced in each sustainable development (Challenge)scenarios - energy and climate.

\begin{tabular}{|c|c|c|c|c|}
\hline & Trend & Global technology & Decentralisated solutions & Consumption change \\
\hline $\begin{array}{l}\text { Access to modern } \\
\text { energy }\end{array}$ & $\begin{array}{l}\text { Access driven by } \\
\text { income trends }\end{array}$ & \multicolumn{3}{|c|}{$\begin{array}{l}\text { Grid investments, subsidies for LPG and micro-credit for related stoves, and distribution of improved biomass } \\
\text { stoves for the poorest households. (Pachauri et al., 2013; } \\
\text { Van Ruijven et al., 2012). }\end{array}$} \\
\hline $\begin{array}{l}\text { Lifestyle } \\
\text { measures }\end{array}$ & $\begin{array}{l}\text { Lifestyle change driven } \\
\text { by income trends }\end{array}$ & Trend & Trend & $\begin{array}{l}\text { Preference for public transport, } \\
20 \% \text { lower material consumption, } \\
\text { recycling of steel, lower heating/ } \\
\text { cooling demand. }\end{array}$ \\
\hline $\begin{array}{l}\text { Energy supply } \\
\text { technology }\end{array}$ & No specific preferences & $\begin{array}{l}\text { Preference for } \mathrm{CCS}, \mathrm{H}_{2} \text { and nuclear } \\
\text { in new investment decisions }\end{array}$ & $\begin{array}{l}\text { Preference for renewable energy } \\
\text { in new investment decisions }\end{array}$ & Trend \\
\hline Efficiency & $\begin{array}{l}\text { Efficiency trends driven } \\
\text { by energy prices }\end{array}$ & $\begin{array}{l}\text { Efficiency improvements in energy } \\
\text { supply, in demand default efficiency } \\
\text { improvement induced by carbon tax. }\end{array}$ & $\begin{array}{l}\text { Implemenetation of best available } \\
\text { technology in residential sector, } \\
\text { service sector and industry } \\
\text { (van den Berg et al., 2011). }\end{array}$ & $\begin{array}{l}\text { Default efficiency improvement } \\
\text { induced by carbon tax. }\end{array}$ \\
\hline Trade & Liberalization & Liberalization & Increased constrains on energy trade & Liberalization \\
\hline Air pollution & $\begin{array}{l}\text { Improvement in } \\
\text { emission factors driven } \\
\text { by income }\end{array}$ & \multicolumn{3}{|c|}{$\begin{array}{l}\text { End of pipe measures based on the GEA scenarios (Riahi et al., 2012). These scenarios were designed to achieve } \\
\text { the WHO guidelines in 2050. The emission factors in the pathways achieve, as a maximum, same emission levels } \\
\text { as the GEA scenarios (emissions can in fact be lower if the systemic changes in the energy system induced by other } \\
\text { measures would already lead to emissions below the level of the GEA scenarios). }\end{array}$} \\
\hline Bio-energy & $\begin{array}{l}\text { Default bio-energy } \\
\text { potential (around } \\
100-200 \mathrm{EJ} / \mathrm{yr} \text { in 2050) }\end{array}$ & \multicolumn{3}{|c|}{$\begin{array}{l}\text { Constrained by sustainability criteria restricting potential for purposely grown bio-energy crops to less than } \\
100 \mathrm{EJ} / \mathrm{yr} \text { in } 2050 \text {. }\end{array}$} \\
\hline
\end{tabular}


Table 5

Key assumptions on water use (focusing only the Global Technology scenario).

\begin{tabular}{ll}
\hline & Global technology \\
\hline $\begin{array}{l}\text { Agriculture/energy } \\
\text { use }\end{array}$ & $\begin{array}{l}\text { All changes as described in Tables } 3 \text { and } 4 \text { are } \\
\text { accounted for in calculating agriculture and } \\
\text { energy system water demand. } \\
\text { Irrigation }\end{array}$ \\
$\begin{array}{l}\text { Efficiency of the irrigation systems is assumed } \\
\text { to be increased to maximum attainable levels } \\
\text { (OECD, 2012) }\end{array}$ \\
$\begin{array}{l}\text { Industry and domestic } \\
\text { water use }\end{array}$ \\
$\begin{array}{l}\text { The scenario assumes wide-spread deployment } \\
\text { efficiency) }\end{array}$
\end{tabular}

emissions are reduced worldwide to meet the WHO guidelines. For this, we have used the regional emission levels of the Global Energy Assessment scenarios - with a similar objective as a target (Riahi et al., 2012)).

Tables 5 and 6 indicate some of additional policy measures that were introduced in order to address water scarcity and the imbalance of the nitrogen cycle. With respect to these issues, we assess both the impacts of the land/biodiversity and energy/ climate policies that are introduced as a limited set of additional measures. For water use, we only concentrate on the Global Technology pathway.

\section{Results of the scenarios}

\subsection{Trend scenario}

The IMAGE model calculations show that the Trend assumptions (including population and income growth) lead to a $50-70 \%$ increase in the demand for agricultural products and energy (consistent with literature ranges (Smith et al., 2010; van Vuuren et al., 2012b)). For agriculture, historically, most of the additional demand has been met through an increase in productivity per hectare, while about 20\% was met by expanding the total agricultural area (Smith et al., 2010). For the future, the gradual slowdown in the rate of agricultural productivity growth and the potential impacts of climate change could imply a larger expansion of agricultural area; on the other hand - the projected slowdown in population growth could soften expansion. In net, the Trend scenario projects global land-use to continue to expand slowly, mostly in Africa (in other parts of the world stabilization or even a small decline is achieved). For energy, the calculations show a strong increase in primary energy supply driven by increasing economic activity and demographic trends. Most of the demand under this scenario is expected to be met by fossil fuels, as their prices are expected to remain below those of renewable energy.

The trends depicted in the IMAGE model allow assessing the developments with respect to sustainable development objectives (Fig. 2). Based on the historical relationships between economic growth, fertility rates and purchasing power of the poor, the scenario is likely to imply a substantial improvement. Still, calculations also show that in 2050 around 200 million people would still suffer from hunger, compared to around 800 million today. Similar to hunger, access to modern energy sources is projected to improve, largely driven by the relatively high economic growth in developing countries. However, due to population growth, persistent poverty and inequality, as well as increasing energy prices, around two billion people will still rely on solid fuels (particularly fuel wood) for heating and cooking by 2050 .

The trend in biodiversity is depicted by the MSA (see method). The Trend scenario projects for the MSA a further decline at an almost linear rate. Historically, agricultural expansion and subsequent loss of natural area has been the most important driver of biodiversity loss. For the future, however, loss of quality driven by climate change, forestry and infrastructure development are projected to become more important factors. With respect to climate change, the trends in energy use mean that greenhouse gas emissions are projected to grow by $60 \%$ between 2010 and 2050 . This means that global mean temperature is projected to surpass the $2{ }^{\circ} \mathrm{C}$ goal well before 2050. By the end of the century, global mean temperature would likely exceed $4{ }^{\circ} \mathrm{C}$.

\subsection{Food and biodiversity}

While the scenarios implemented all targets simultaneously, we discuss them here in the two main clusters for presentation purposes. The overarching objective of the food and biodiversity cluster is to eradicate hunger and maintain a stable and sufficient food production by 2050 while conserving biodiversity and ecosystems (see Table 1). The ambition to achieve these targets has to be realized against the backdrop of $60 \%$ to $70 \%$ higher demand for agricultural production due to a much larger and wealthier population (see Section 3.1). Moreover, there is also an increased demand for modern bioenergy (see 3.3), although the sustainability criteria restrict the use of purposely grown woody bio-crops to around $50 \mathrm{EJ} / \mathrm{yr}$. Below, we present the results of the main assumptions

Table 6

Key assumptions related to the nitrogen cycle.

\begin{tabular}{|c|c|c|c|c|}
\hline & Trend scenario & Global technology & Decentralised solutions & Consumption change \\
\hline $\begin{array}{l}\text { Fertiliser-use } \\
\text { efficiency }\end{array}$ & $\begin{array}{l}\text { Some improvement in utilization } \\
\text { efficiency, but still increase in } \\
\text { fertilizer use to sustain } \\
\text { additional food production }\end{array}$ & $\begin{array}{l}\text { Fertiliser-use efficiency } \\
\text { improved by } 50 \% \text { for } \\
\text { extra yield increase }\end{array}$ & $\begin{array}{l}\text { Fertiliser-use efficiency improved by } \\
50 \% \text { for extra yield increase }\end{array}$ & $\begin{array}{l}\text { Fertiliser-use efficiency } \\
\text { improved by } 50 \% \text { for } \\
\text { extra yield increase }\end{array}$ \\
\hline $\begin{array}{l}\text { Animal } \\
\text { excretions }\end{array}$ & $\begin{array}{l}\text { Decreases with increasing } \\
\text { productivity }\end{array}$ & $\begin{array}{l}15 \% \text { lower excretion } \\
\text { rates due to high } \\
\text { feed-use efficience }\end{array}$ & $5 \%$ lower excretion rates than in trend & $\begin{array}{l}\text { Decreases with increasing } \\
\text { productivity }\end{array}$ \\
\hline $\begin{array}{l}\text { Manure } \\
\text { integration }\end{array}$ & No & No & $\begin{array}{l}\text { Manure is recycled and better } \\
\text { integrated in the agricultural system }\end{array}$ & No \\
\hline $\begin{array}{l}\text { Recycling of } \\
\text { human excreta }\end{array}$ & No recycling & No recycling & $\begin{array}{l}\text { Recycling of human } \mathrm{N} \text { and } \mathrm{P} \text { from households } \\
\text { with access to improved sanitation }\end{array}$ & No recycling \\
\hline
\end{tabular}




\section{Key indicators of sustainability in the Trend scenario}

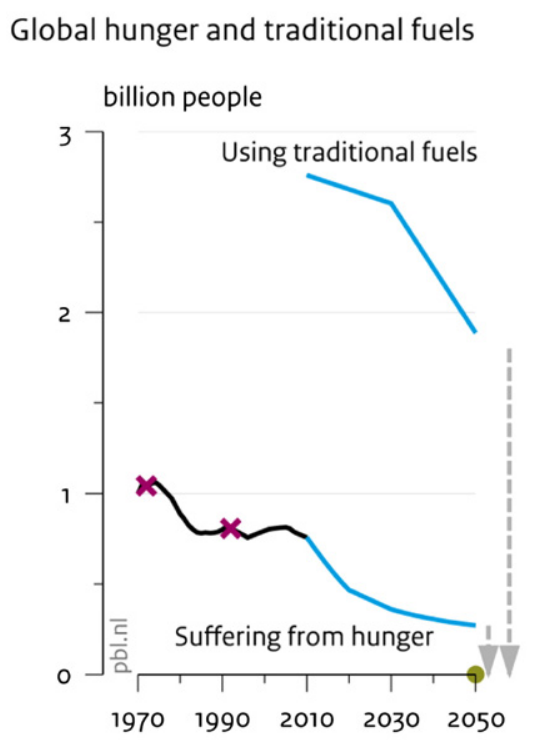

Global biodiversity

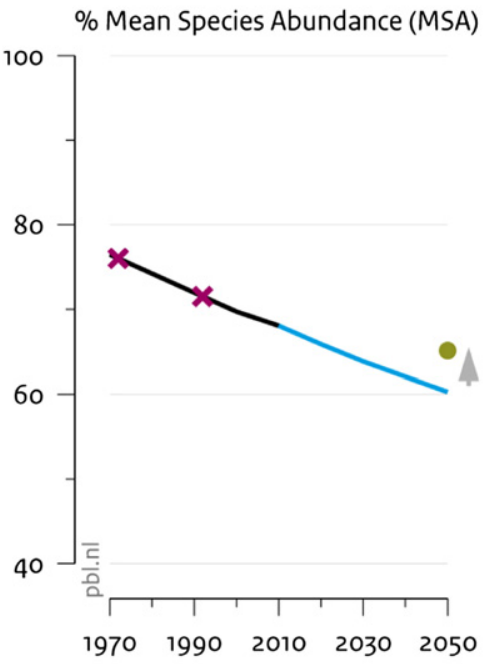

Global greenhouse gas emissions

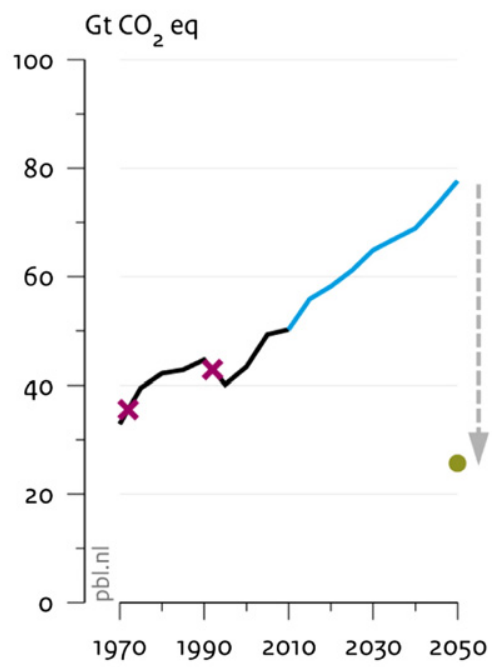

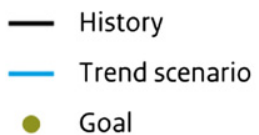

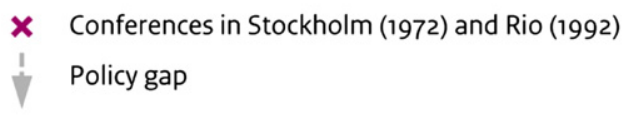

Fig. 2. Key results for the Trend scenario versus the objectives described in Table 1.

introduced in Table 3 (assuming that the political will would exist to implement them, see also discussion).

\subsubsection{Access to sufficient food}

Fig. 3 shows the total caloric consumption level in each region, as well as the relative importance of the drivers of increased demand; that is, population growth (directly influencing volume) and income growth (leading to more consumption per person and dietary changes). Ensuring that the food system will be able to supply this additional demand as a result of the overall increase in demand clearly presents a formidable challenge. The additional objectives adopted in the Challenge Scenarios are that of eradicating hunger by 2050 through different combinations of increase in agricultural production increases and/or more equitable access to food (representing policies targeting the poorest groups within society) (see Table 3). The calculations show that the additional food production to eradicate hunger (left panel, Fig. 3) is only small compared to total production levels for 2050. This is especially the case for the decentralized solution and consumption change scenarios in which increased production is combined with targeting the poorest households. The implication of this finding is that providing full access to food does not need to represent a serious trade-off with the objective to also conserve biodiversity.

\subsubsection{Biodiversity loss}

In the Trend scenario, the MSA showed a significant loss of biodiversity up to 2050 (Fig. 2 and left-hand side Fig. 4). The calculations show that in the three Challenge Scenarios different combinations of policy measures (Table 3) can achieve the objective of stabilizing biodiversity loss at 2020 levels (righthand side Fig. 4). Under the Global Technology pathway the most important contribution comes from increasing agricultural productivity on highly productive lands (Fig. 4) (more than $60 \%$ of the MSA loss is prevented in this way). This has, however, considerable implications for the required yield levels as discussed in the next paragraph. Under the Consumption Change pathway, significant reduction in the consumption of meat and eggs as well as reduced wastage means that less agricultural production would be required, thus, reducing the associated biodiversity loss (closing the gap by nearly 25\%). Under the Decentralized Solutions pathway, a major contribution would come from avoiding fragmentation, more ecologically sound farming and reduced infrastructure expansion (together about a third of the original gap). Under all scenarios, climate change mitigation, the expansion and effective management of protected areas and the recovery of abandoned lands also significantly contribute to reducing biodiversity loss.

\subsubsection{Agricultural productivity}

In all Challenge Scenarios a substantial increase in agricultural productivity is required compared to the Trend scenario to respond to the dual challenge of providing sufficient food to sustain 9 billion people and to protect biodiversity. Under the Trend scenario, the annual growth in agricultural productivity is projected to decline further in line with the trend over the past 15 years (see Fig. 5 for cereals). This is partly caused by the fact that, in different parts of the world, yields are getting closer to potential maximum achievable levels and the easiest measures 


\section{Global calorie consumption}

Per driver

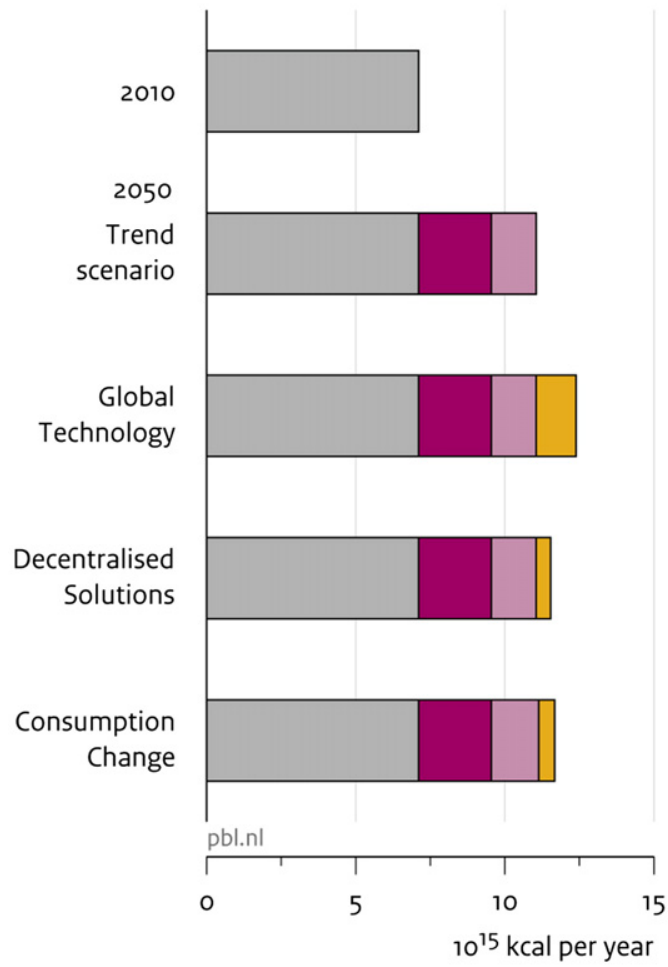

2010

Additional consumption in $2010-2050$ period resulting from

Population growth

Income growth / consumption change

Additional policies to eradicate hunger
Per region

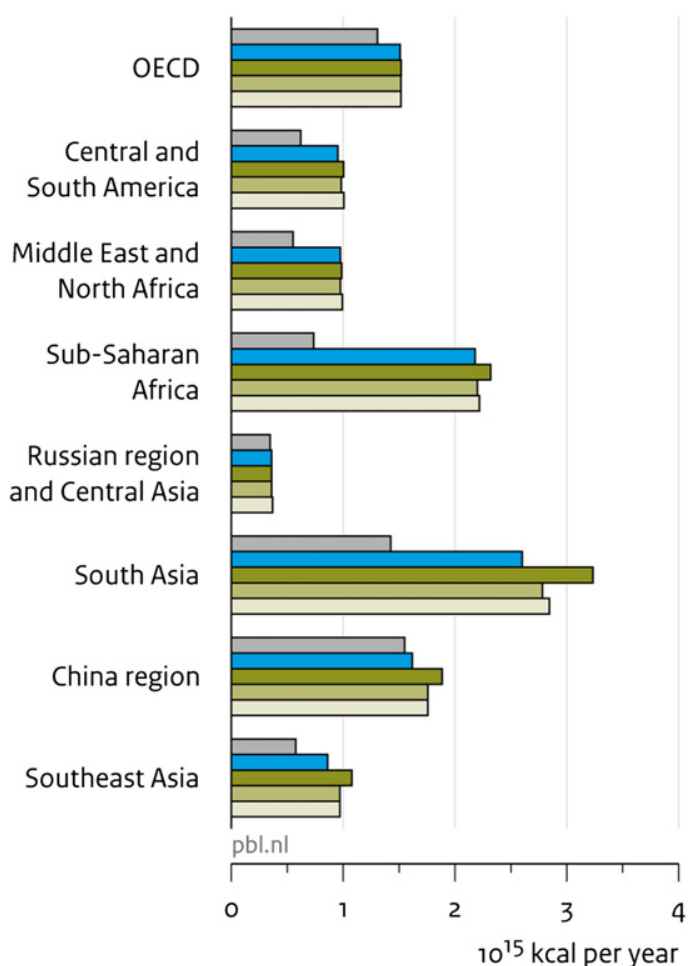

2010

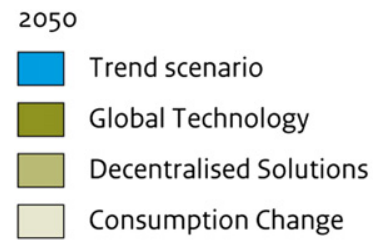

Fig. 3. Global calorie consumption in the Trend scenario and the 3 Challenge Scenarios.

have already been implemented. In the Challenge Scenarios, a much higher productivity is needed to achieve the joint biodiversity and hunger eradication goals (see also Brussaard et al., 2010). In fact, the required increase in productivity would be the highest under the Global Technology pathway, which is twice that of the Trend scenario (1.3\% annual increase versus $0.6 \%$ ). In the other two Challenge Scenarios, productivity improvements also need to be significantly above the Trend scenario level. Several technological options exist for increasing yields in a sustainable way, which vary from further developing high-yield breeds, closing yield gaps in various parts of the world, and improvements in agricultural management which could be applied in the various farming systems (Godfray et al., 2010; PBL, 2012; Rabbinge and Bindraban, 2012). The relatively low yields achieved in some developing countries, in particular in sub-Saharan Africa, signal significant potential for improvement, although, to date, socio-economic factors have acted as barriers in this respect. The consequences for nitrogen and water use of the yield improvement in these scenarios has been accounted for.

The Consumption Change pathway shows that the consumption of fewer animal products and reductions in food losses considerably reduce the need to increase yields for achieving the joint food production/biodiversity objective (Fig. 4). The production of livestock products demands large tracts of land for feed and fodder production, because of the inefficiencies in converting feed into meat and dairy produce. The reduction of post-harvest and supply chain wastes and losses represent a substantial (15\%) effective gain in supply, without requiring additional land.

In terms of the comparison of the Global Technology versus Decentralized solutions scenarios, the results show that both pathways (lined up with the "land sparing" versus "land sharing" debate in the literature) have significant scope for increased and more sustainable production, but they also rely on improved land-use planning (Bennett and Balvanera, 2007; 


\section{Global biodiversity and options to prevent biodiversity loss}

\section{Global biodiversity}

$\%$ Mean Species Abundance (MSA)

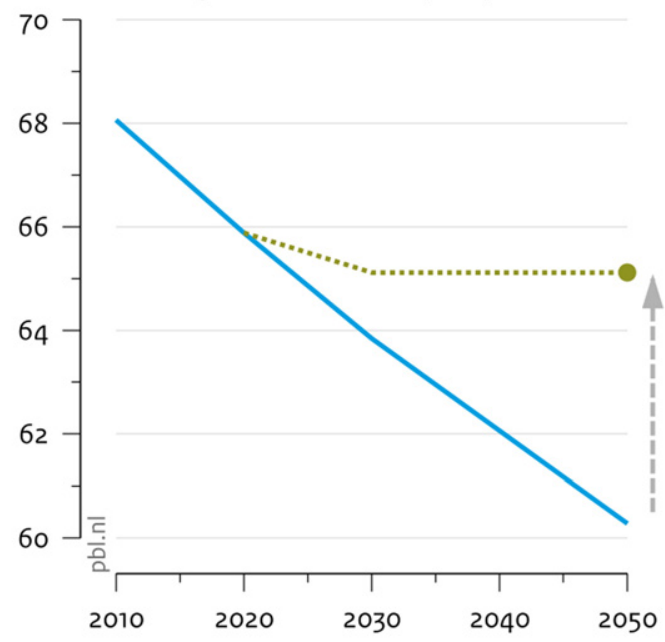

\section{Contribution of options to prevent} biodiversity loss, 2050

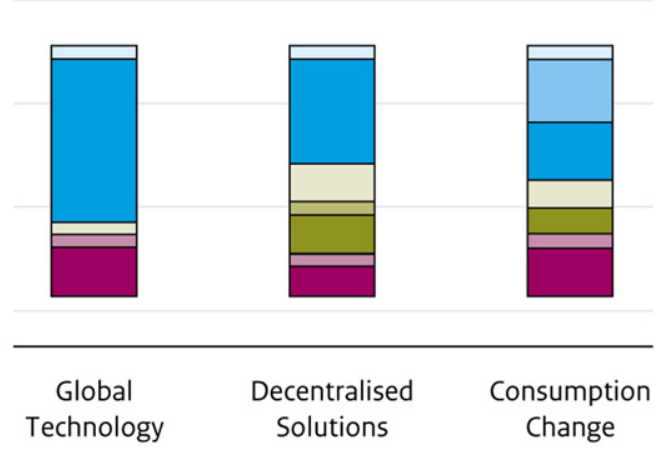

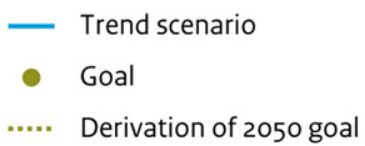

Policy gap
Restore abandoned agricultural lands

Reduce consumption and waste

Increase agricultural productivity

Expand protected areas

Reduce nature fragmentation

Reduce infrastructure expansion

Reduce nitrogen emmissions

Mitigate climate change

Fig. 4. Measures used in the scenarios to prevent biodiversity loss, Trend scenario and three Challenge Scenarios.

Godfray et al., 2010). Multifunctional landscapes (land sharing) may offer areas of agriculture that are highly interwoven with nature areas, improving local ecosystems and connectivity between natural areas (Lambin and Meyfroidt, 2011). It is likely that such an approach would lead to somewhat lower production intensities compared to mono-functional

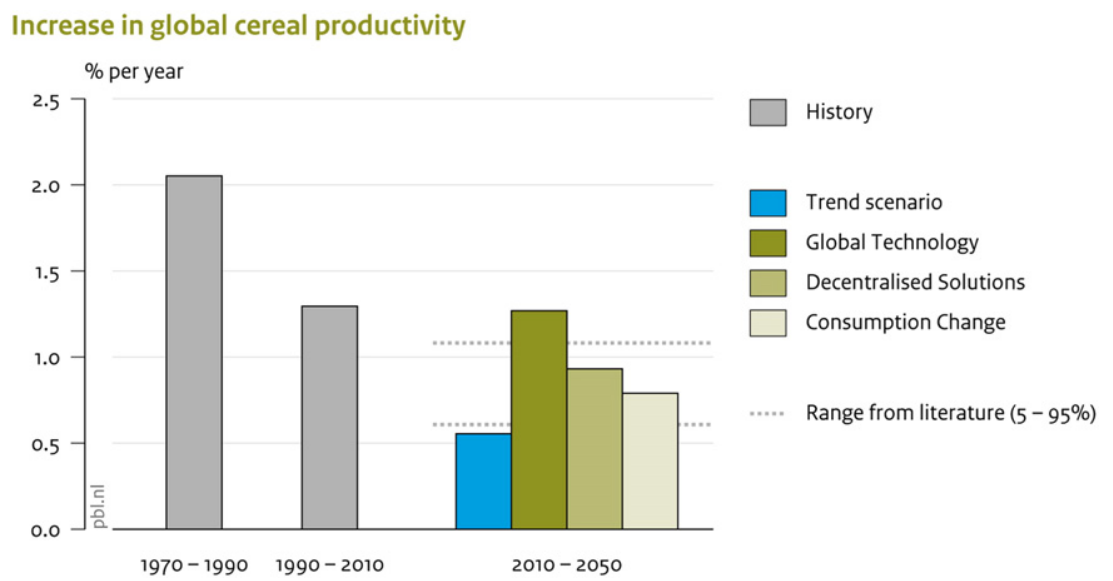

Fig. 5. Required increase in global cereal productivity. Trend scenario and the three (Challenge) Sustainable Development Scenarios. 
landscapes. On the other hand, while mono-functional landscapes ("sparing approach") could lead to more local biodiversity loss, the strong emphasis on resource efficiency using cutting edge precision technologies to achieve agronomic optimization of the farm environment may lead to a favorable result at the global scale (Rabbinge and Bindraban, 2012). In multifunctional landscapes, high yields may potentially still be achieved by combining technological advances with the services provided by natural processes (Bennett and Balvanera, 2007). In fact, the differences between these systems may become smaller due to the current direction of agricultural research, allowing for improved production in agro-ecological systems and reduced impacts in intensive systems.

\subsection{Energy and climate}

With respect to energy and climate, the sustainable development challenge can be summarized so as to ensure access to modern sources of energy for all, while substantially reducing greenhouse gas emissions as well as air pollution. In the Trend scenario, none of these objectives are achieved (Section 3.1). In our Challenge Scenarios, we assume that existing barriers for environmental policy (see Section 3.5) can be overcome by implementing the measures described in Table 4.

\subsubsection{Access to modern energy}

There are multiple benefits associated with ensuring access to modern energy, including avoiding health impacts from indoor air pollution, improved income and educational opportunities due to reduced time spent on collecting firewood and reduced environmental impacts such as deforestation and the black carbon emissions. In our modeling framework, in order to improve access to modern energy we assume $80 \%$ fuel price support on LPG coupled with more easy credit access (Van Ruijven et al., 2012) and a $95 \%$ grid connectivity in 2030, mainly through massive grid expansion in rural areas in South Asia and sub-Saharan Africa (Daioglou et al., 2012). Our calculations show that this could lead to significant increase in access to modern energy. Nevertheless, due to remaining poverty, the calculations also show that many households would still not be able to make the transition to modern fuels. For these households, we assume the distribution of improved biomass stoves, as a cost-effective interim solution. These stoves are more efficient and less polluting than conventional ones, and the additional investment in improved stoves could be fully countered through reduced spending on firewood (Hutton et al., 2006). The total cost of achieving universal access to modern energy sources is estimated at around USD 70 billion, for the 2010-2030 period (Pachauri et al., 2013). The economic benefits of improving health and providing development opportunities are expected to more than outweigh these costs (Hutton et al., 2006; Pachauri et al., 2013). Interestingly, our calculations suggest that providing access to modern energy source would not present a trade-off with climate mitigation (Fig. 6). The reasons are that the 1) per capita energy consumption of the people involved would (initially) be very low, 2 ) modern energy sources are more efficient than traditional ones, and 3) a decreased use of traditional biofuels also reduces deforestation and black carbon emissions. It should be noted that climate policies that increase fossil fuel prices could potentially make the transition to modern energy sources more difficult. Climate policies should thus be designed in a way that negative impacts on poor households are avoided.

\subsubsection{Climate change}

In order to reach the $2{ }^{\circ} \mathrm{C}$ target, global emissions would need to be reduced by around $40-50 \%$ by 2050 (Van Vuuren et al., 2007; van Vuuren et al., 2011), instead of the 60\% increase depicted under the Trend scenario (Fig. 2 and left-hand side Fig. 7). Various scenarios have been published in the literature, each with a different emphasis on technological and behavioral changes (Edenhofer et al., 2010; Riahi et al., 2012; Riahi et al., 2015). The Challenge Scenarios have somewhat different portfolios (Table 4) depending on the assumed preferences and technology development rates. Fig. 7 shows how different mitigation measures contribute to the emission reductions required to achieve the $2{ }^{\circ} \mathrm{C}$ target, while Table 7 summarizes the consequences for the energy system, both on the basis of our scenarios and of existing literature. The most important measures implemented in the scenarios include:

- Reducing non- $\mathrm{CO}_{2}$ greenhouse gases, such as the recovery of $\mathrm{CH}_{4}$ from landfills and coal mining, is relatively inexpensive (Lucas et al., 2007) and can contribute to about 20\% of total emission reductions (Fig. 7). There are key co-benefits associated with these measures (e.g. $\mathrm{CH}_{4}$ emission also leads to lower ozone levels). However, the potential for non- $\mathrm{CO}_{2}$ emission reduction is limited, as they account for only around $20 \%$ of total $\mathrm{CO}_{2}$-equivalent emissions and some emissions sources are very difficult to abate (e.g. $\mathrm{CH}_{4}$ emissions from ruminant livestock and $\mathrm{N}_{2} \mathrm{O}$ emissions from fertilizer use).

- Energy efficiency improvements play a key role, in particular in the Consumption Change and decentralized solutions scenario where they account for around $25 \%$ of total reductions. In order to accomplish this, the energy efficiency improvements have to occur at double the historical rate. Although historical evidence has shown that it might not be easy to harvest this opportunity, there is evidence that particular measures, such as standards, energy service companies, optimization of material flows and the enforced adoption of best available technologies, could significantly higher improvement rates (GEA, 2012).

- Low- and zero-carbon energy sources together provide 50\% to $90 \%$ of the world's primary energy by 2050 (see Table 7). This can be renewables (especially in Decentralized Solutions), bio-energy, carbon capture and storage (CCS) and/or nuclear energy (the latter two especially in Global Technology). Many of these options come with their own challenges with respect to implementation and/or sustainability issues and their implementation would require further development of infrastructure. There is some evidence that financial instruments such as emission trading schemes, taxation and, first and foremost, the removal of subsidies on fossil fuels - could be successful to stimulate a transition.

The fundamental character of this shift can be illustrated by the decarbonisation rate of the global economy, i.e. the reduction in the ratio between $\mathrm{CO}_{2}$ emissions and GDP (Fig. 8). Historically, the highest five-year improvement occurred during the 1980 s at around $2 \%$ annually, driven by the high energy prices of the late 1970s and early 1980s and subsequent government response programs (see also (GEA, 2012)). Under the Trend scenario, the historical annual rate of $1 \%$ to $2 \%$ is 


\section{Global household access to modern fuels and $\mathrm{CO}_{2}$ emissions}

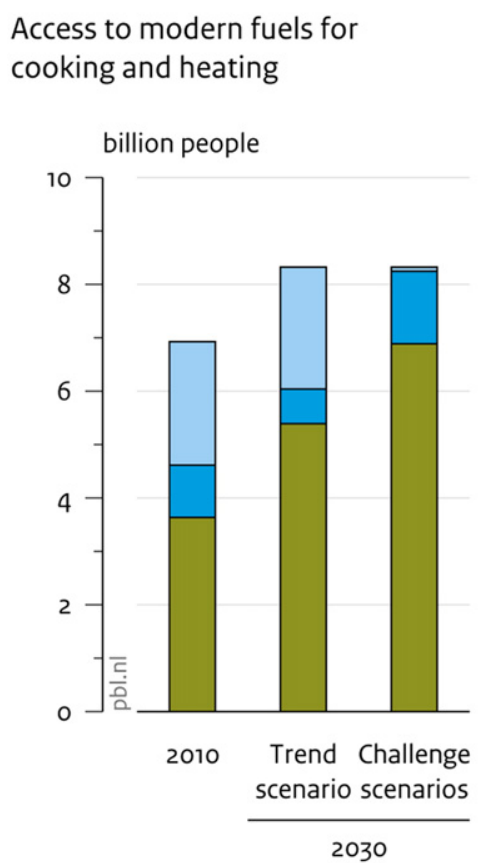

Access to electricity

Household $\mathrm{CO}_{2}$ emissions
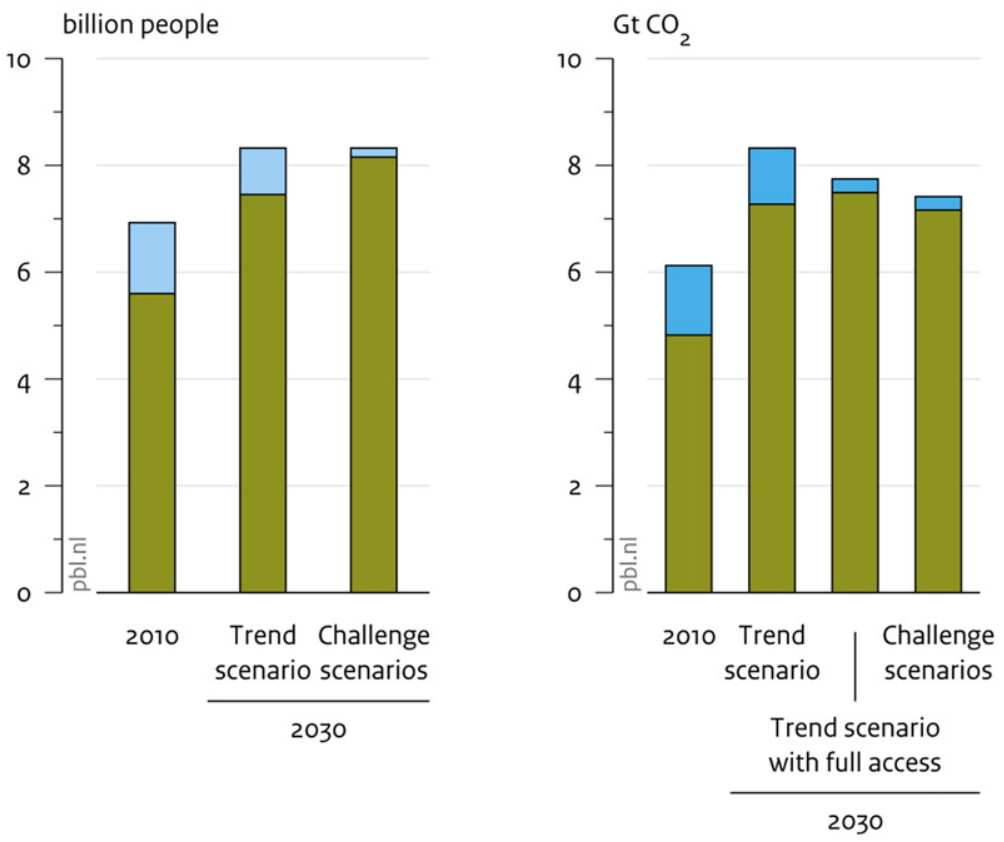

No access

Access
Traditional bio-energy

Fossil fuels

Fig. 6. Access to modern fuels and corresponding changes in household $\mathrm{CO}_{2}$ emissions. The Trend scenario with full access refers to a sensitivity run in which we implemented the full-access goal only (and not the other sustainability objectives of the Challenge Scenarios).

projected to continue. To achieve the $2{ }^{\circ} \mathrm{C}$ target, however, the decarbonisation rate must reach a level of around $4.5 \%$ in the three Challenge Scenarios over the 2010-2050 period. The rate is projected to increase slowly to an annual improvement rate of $5 \%$ to $6 \%$ around 2030 , around three to four times the historical rate (Van Vuuren and Stehfest, 2013).

The emission reductions assumed in the Challenge Scenarios would likely lead to an increase in global mean temperature of less than $2{ }^{\circ} \mathrm{C}$ (Van Vuuren et al., 2007). Uncertainties in the climate system, however, imply that warming may also be $3{ }^{\circ} \mathrm{C}$ or more, even if emission reductions are successful. In other words, countries will still need to adapt to climate change to deal with the impacts of a $2{ }^{\circ} \mathrm{C}$ warming and possibly more than that. While many adaptation measures to climate change can be introduced relatively quickly, some adaptation measures take time, such as coastal protection and adapting urban planning (Patt et al., 2010) as well as agricultural systems.

\subsubsection{Air pollution}

Fuel combustion is currently responsible for a large proportion of the five million premature deaths each year from air pollution and for more than $8 \%$ of all ill health (Smith et al., 2012). In the Trend scenario, the trends in fossil fuel use imply that emissions of air pollutants stay globally at high levels despite improvement of emission factors (Fig. 9). A substantial part of the emission reductions in the Challenge Scenarios, in fact, occur as co-benefits of the changes in the energy system induced by climate policy as calculated using the IMAGE model (Chuwah et al., 2013). However, these emission reductions are not enough to meet the WHO guidelines everywhere. Therefore, further emission reductions had to be introduced by using end-of-pipe abatement technologies in our calculations represented by reducing emission factors (the necessary changes vary slightly across the different scenarios). The resulting emission reductions are shown in Fig. 9.

\subsection{Interlinkages between different sustainable development objectives}

Other key challenges for sustainable development are directly related to land use and energy trends, such as preventing water scarcity, reducing the imbalances in the Earth's nutrient cycles and preventing damage to human health. These challenges are briefly discussed below, in terms of the relationships with the issues discussed previously, but also in terms of the effectiveness of additional measures. 


\section{Global greenhouse gas emissions and options to reduce emissions}

\section{Greenhouse gas emissions}

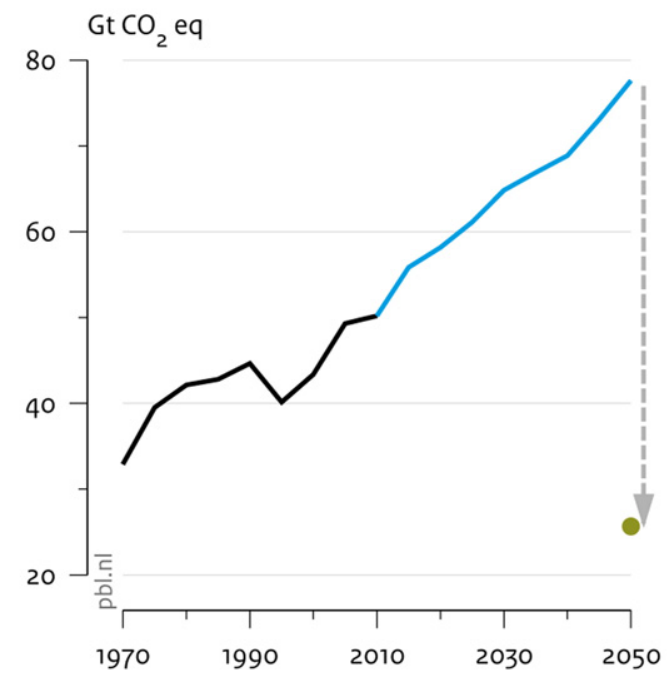

\section{Contribution to cumulative emission reduction, $2010-2050$}

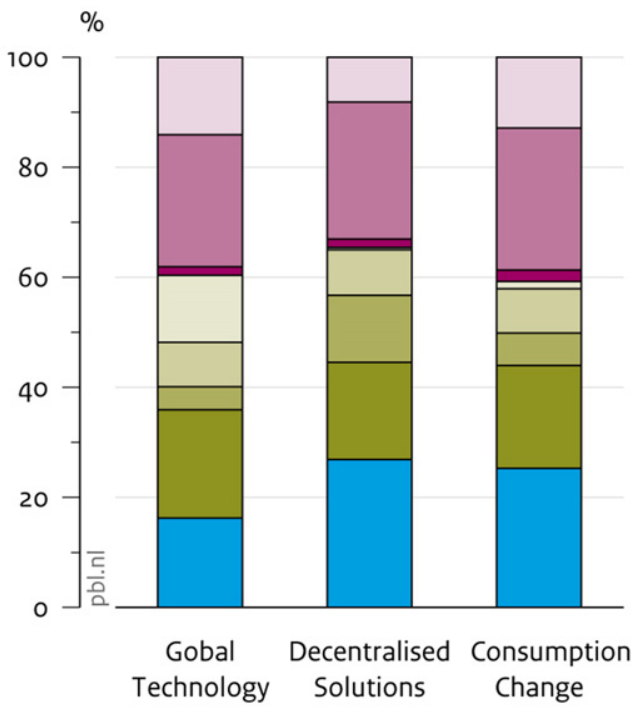

Avoid deforestation

\section{Reduce other greenhouse gases}

Reduce other energy-related emissions

Increase nuclear power

Increase bio-energy

Increase solar and wind power

Increase $\mathrm{CO}_{2}$ capture and storage

Improve energy efficiency

Fig. 7. Different measures taken in the various Scenarios to achieve the $2{ }^{\circ} \mathrm{C}$ target.

\subsubsection{Water scarcity}

Many regions worldwide are seriously affected by an imbalance between availability and withdrawal of water (water stress, defined as a ratio of water demand over supply larger than 0.4). Based on the outcomes of the agriculture and energy scenarios presented in Sections 3.2 and 3.3, and external scenarios for industrial and residential water use (Ozkaynak et al., 2012) it is possible to calculate future water demand under the Trend and Challenge Scenarios. This can subsequently be used to estimate the possible changes in water stress using the LPJ water model included in IMAGE, taking into account the expected change in precipitation as a result of climate change (Fig. 10). The calculations show that agriculture is the main user of water, while water use is increasing most rapidly in the industrial and energy sectors. Water demands are projected to increase strongly, under the Trend scenario, with many regions

Table 7

Share of different technology categories in world energy production, trend scenario and the three sustainability scenarios.

\begin{tabular}{|c|c|c|c|c|c|c|c|c|c|}
\hline & \multirow[t]{4}{*}{2000} & \multicolumn{8}{|l|}{2050} \\
\hline & & \multicolumn{3}{|l|}{ Trend } & \multicolumn{5}{|c|}{ Alternative scenarios } \\
\hline & & \multirow[t]{2}{*}{ This study } & \multicolumn{2}{|c|}{ EMF22 } & \multicolumn{3}{|c|}{ This study } & \multicolumn{2}{|c|}{ EMF22 } \\
\hline & & & Avg & Range & GT & $\mathrm{CC}$ & DS & Avg & Range \\
\hline Fossil fuel & 81 & 80 & 79 & $68-95$ & 40 & 42 & 40 & 35 & $13-48$ \\
\hline Fossil fuel + CCS & 0 & 0 & 0 & $0-0$ & 12 & 20 & 17 & 20 & $0-31$ \\
\hline Bio-energy & 9 & 6 & 9 & $0-13$ & 13 & 14 & 16 & 15 & $0-28$ \\
\hline Nuclear energy & 6 & 4 & 3 & $1-6$ & 22 & 6 & 2 & 14 & $3-37$ \\
\hline Other renewables & 5 & 10 & 9 & $2-14$ & 14 & 18 & 25 & 16 & $8-24$ \\
\hline
\end{tabular}

Note: EMF22 numbers refer to the range of outcomes of the model comparison study coordinated by EMF on different climate policy scenarios (Clarke et al., 2010). 


\section{Global decarbonisation rate}

Decarbonisation

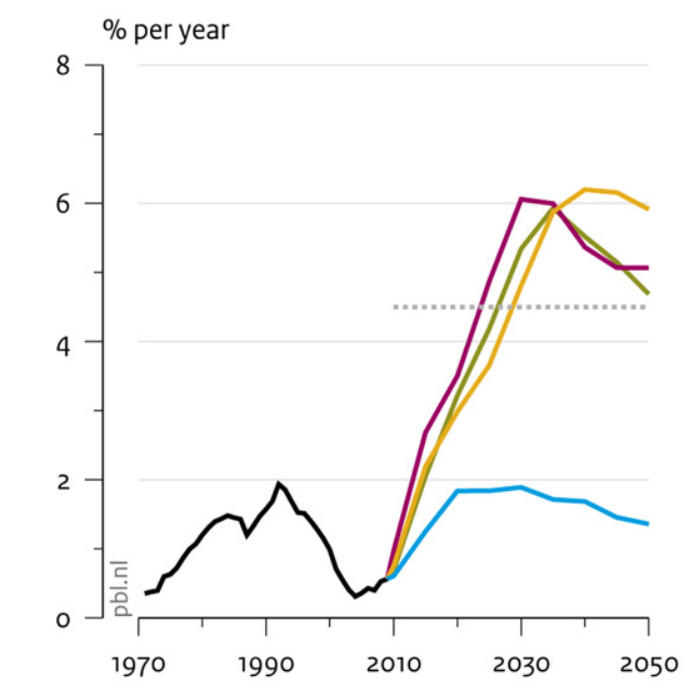

- History

\section{Underlying factors}

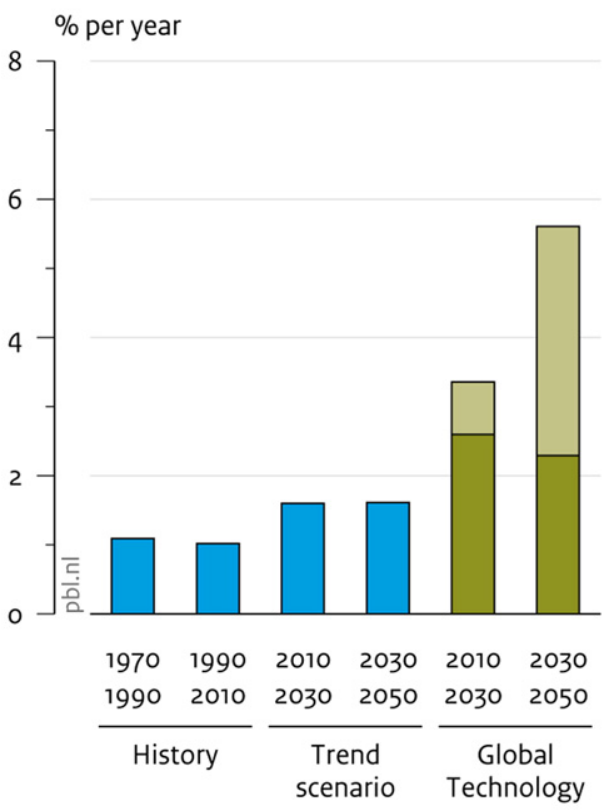

Total

Decarbonisation by decrease in

$\mathrm{CO}_{2}$ emissions from energy production

Energy intensity

\section{Average for Global Technology}

Fig. 8. Decarbonisation rate of the different scenarios.

worldwide seriously affected by water stress (consistent with Arnell et al. (2011)). Key drivers of the increased number of people exposed to water stress are 1) the doubling of water demand and 2) population growth in water scarce regions. The result is a doubling of the number of people living under conditions of severe water stress in the 2010-2050 period. While in the Challenge Scenarios, water demand is substantially lower, as a result of changes in agricultural production and climate policy in the energy system (mainly by reducing demand for thermal cooling) in the scenarios we also assumed efficiency measures (Table 5). A key result, however, is that while the Challenge Scenarios lead to less water demand, still more people live in water scarce areas in 2050 than today as a result of the population growth in water scarce areas.

\subsubsection{Impacts on the nitrogen balance}

Another major environmental problem related to the sustainable development issues discussed so far is the imbalance in the global nitrogen cycle (Bouwman et al., 2009; Rockström et al., 2009; Steffen et al., 2015). In order to sustain the increasing food production in the Trend and Challenge Scenarios, nitrogen and phosphorus fertilizer use are projected to increase (based on the modelled yield increases). This increase will be particularly strong in developing countries. It is possible to somewhat mitigate this by specific measures, including significant improvements in crop and livestock production, recycling of human excreta and a better integration of animal manure in crop production systems. Nevertheless, despite the reduction of fertilizer use that is possible compared to the Trend scenario, there would still be an increase from today's levels, primarily in transitional and developing countries. Fig. 11 shows the nitrogen imbalance according to our calculations.

\subsubsection{Human health}

An important co-benefit of achieving the set of objectives occurs for human health. As defined by the objectives, in the Challenge Scenarios, by 2050, hunger is eradicated and there will be full access to safe drinking water, basic sanitation and modern energy. As a result, our calculations project important improvements in the global health situation, especially for children under five, by significantly reducing the incidence and mortality of diarrhea and respiratory infections. The calculations show that achieving the objectives could avoid roughly 800,000 child deaths annually by 2050 compared to the situation under the Trend scenario (Fig. 12). The results also 


\section{Global emissions of air pollutants}

Black carbon

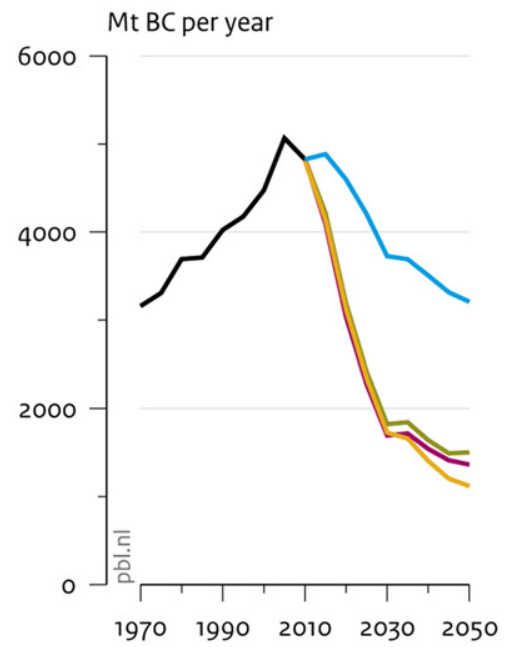

Sulphur dioxides

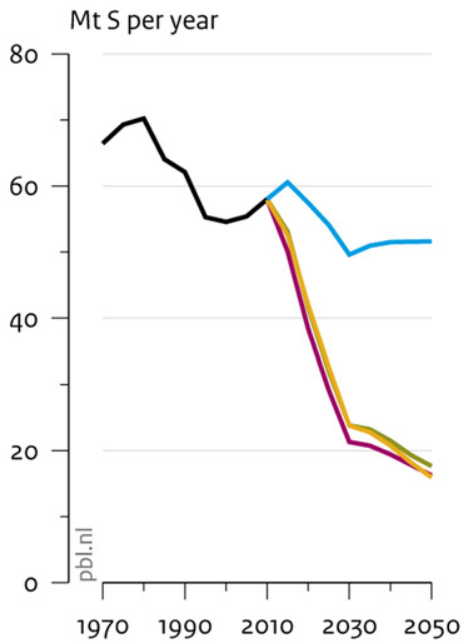

Nitrogen dioxides

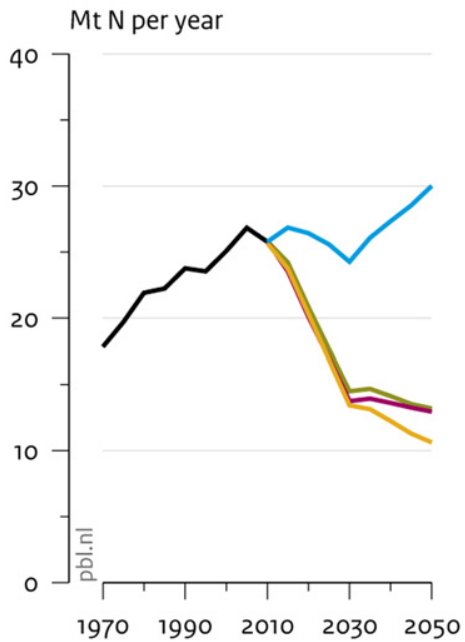
— History
- Global Technology
- Trend scenario
- Decentralised Solutions
- Consumption Change

Fig. 9. Air pollutants in the various scenarios.

\section{People in water stressed areas, per region}

$$
2000
$$

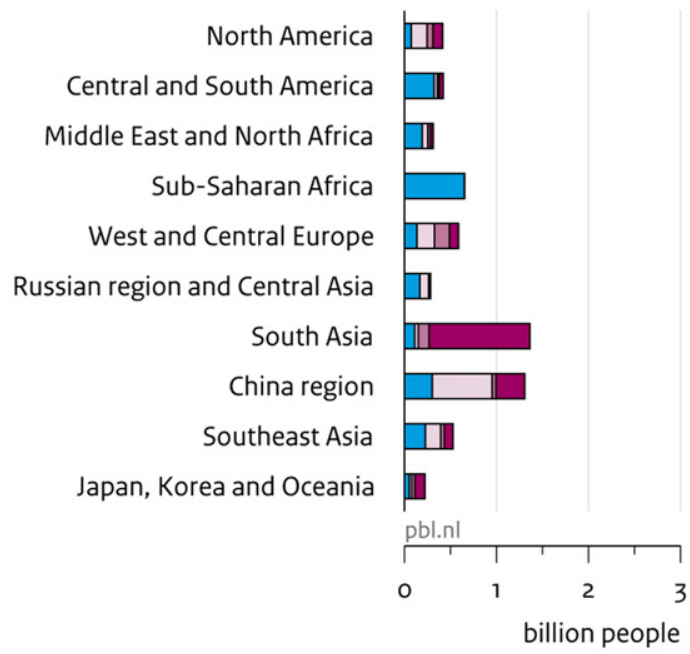

Trend scenario, 2050

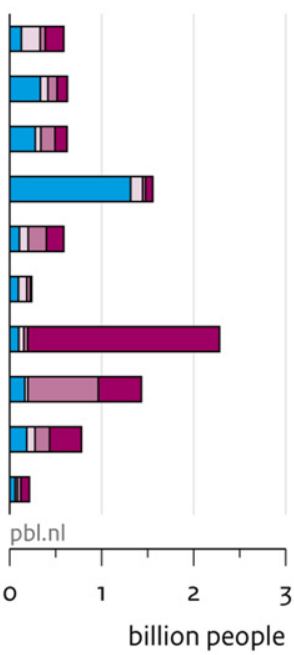

Global Technology, 2050

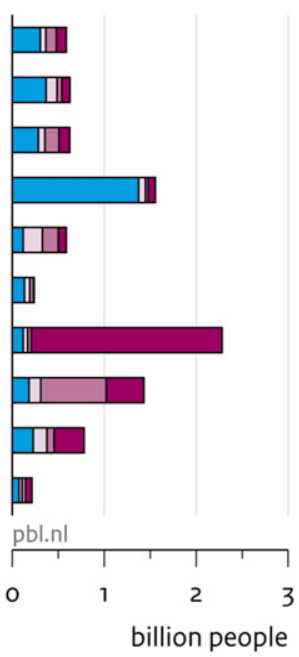

No water stress

Low water stress

Medium water stress

Severe water stress

Fig. 10. People in water stressed areas in the various scenarios. Global Technology scenario has been used for illustration of the Challenge Scenarios (other scenarios only slightly differ). 


\section{Global nitrogen surplus}

Trend scenario

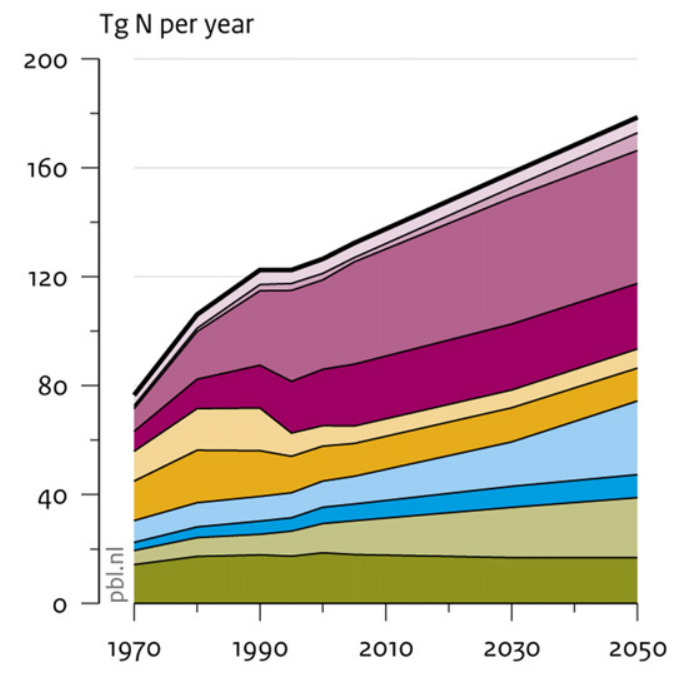

Per pathway, 2050

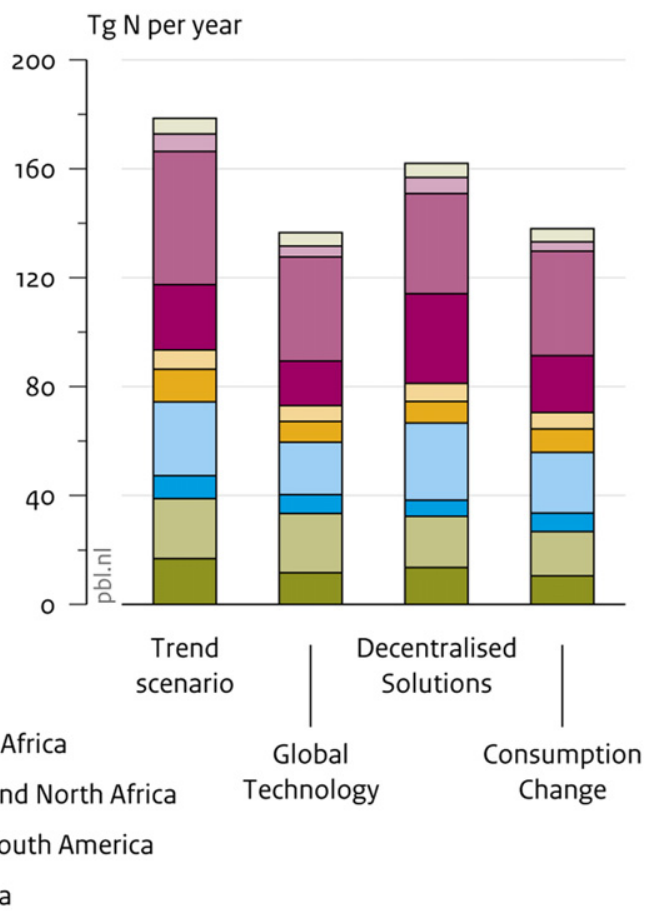

Japan, Korea and Oceania

Southeast Asia

China region

South Asia

Russian region and Central Asia

West and Central Europe

Fig. 11. Global nitrogen surplus in the various scenarios.

show, however, that this will be insufficient to meet the MDG target on child mortality (which is to reduce the under-five mortality rate by two thirds between 1990 and 2015) even before 2030. To further reduce mortality, policies that address access to food, water and energy should also include certain quality aspects of access related to hygiene, indoor venting and clean fuels. Furthermore, the broader socio-economic setting should be improved as well, including health services and health education, with a specific focus on female education. It should be noted that, although reducing the risk factors for infectious diseases would lead to many healthy life years gained, at the same time the disease burden of chronic diseases is likely to increase, especially at advanced ages. In fact, in the Trend scenario by 2030, the two most dominant chronic diseases (cardiovascular disease and cancers) are projected to make up around $50 \%$ of all global deaths. Although these diseases are also related to several environmental risk factors connected to food consumption, air pollution, climate change, and a poor quality of the physical environment (e.g. through physical inactivity, unfavorable diets, obesity, urban air pollution and heat and cold stress) their relationship is less strong and the diseases mainly affect the elderly and not the children under five. The improved air quality in the Challenge Scenarios decreases related mortality significantly, while projected urbanisation and ageing dampen the effect of reduced exposure on overall mortality. Furthermore, the eradication of global hunger through increasing food production also increases food consumption for the better nourished, thereby increasing obesity and related mortality (PBL, 2012).

\subsubsection{An overall assessment of linkages and trade-offs}

We have used the results of our scenarios and some further information in the literature to summarize the different synergies and trade-offs between the objectives as identified in this study (Table 8). We briefly discuss some of the key conclusions that can be derived from Table 8. First of all, several important synergies can be identified (green cells):

- In the energy field, Table 8 identifies several possible synergies. This means that an integrated approach to achieving climate, air pollution and energy security targets could lead to significant cost reductions. Reducing air pollution, for instance, would lead to important synergies for climate change mitigation (depending on the type of air pollution), improve access to food and protect biodiversity. These benefits would be immediate, which could raise the appraisal of these measures.

- Sustainable access to enough food, safe drinking water, improved sanitation and modern energy sources would improve health, significantly - especially for small children. It would also create wealth, both directly and indirectly; for example, by freeing up time to be used for activities other 
Global child deaths per cause

\section{People suffering from hunger}

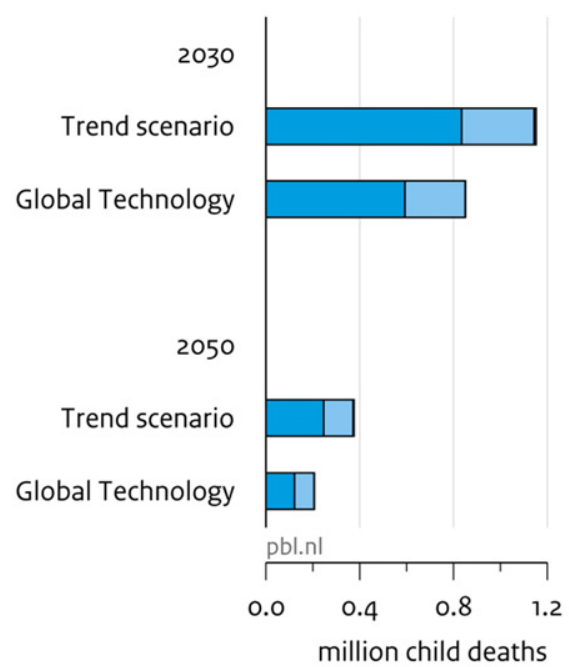

People without access to safe drinking water or basic sanitation

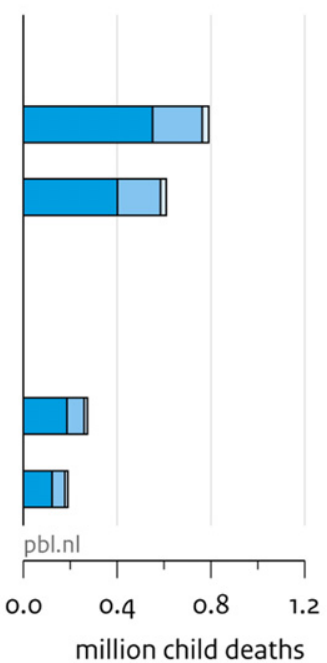

People using traditional energy for cooking and heating

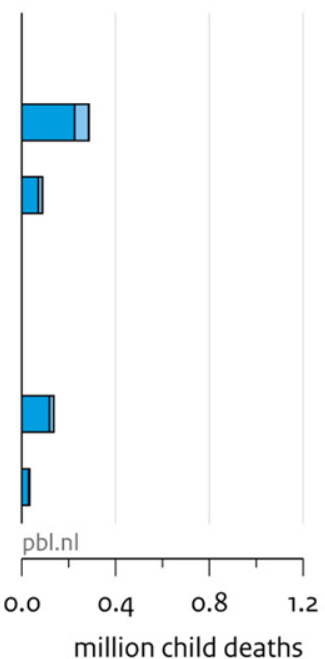

Sub-Saharan Africa

South Asia

Rest of the world

Fig. 12. Trends in number of global child deaths in the Trend and Global Technology scenarios.

than the collection of water and firewood.

- Sound ecosystem management and restoration of degraded ecosystems may result in cleaner and more reliable water sources, higher carbon uptakes by natural areas, and improved soils that would sustain a higher agricultural production.

- Changing dietary patterns may also have important cobenefits. It would not only help to reduce biodiversity loss, but it would also contribute to achieving the climate objective.

- Important linkages (both synergies and trade-offs) also exist between increased food production and climate change.

There are also several trade-offs (red cells)

- A major trade-off involves bio-energy. This could help to achieve the climate objective, but would complicate achieving those for biodiversity and food. Here, sustainability criteria and monitoring would be needed to keep the negative impacts within acceptable bounds.

- Providing access to food for all may also result in several trade-offs, with climate (as a result of additional land and fertilizer use) and biodiversity protection. This study shows that these negative impacts can be compensated, but obviously require additional measures.

- Biodiversity protection may have negative trade-offs for access to food.

The synergies and trade-offs work out differently across the different scenarios. In the Global Technology scenario, the key trade-offs center across the impacts of technology solutions, such as increased use of fertilizer, irrigation and fossil fuel use with CCS. In the Decentralised Solutions scenario, instead, a key risk (and thus potentially trade-off) centers around the effectiveness of multifunctional land-use and penetration of decentral renewable energy options. Finally, in the Lifestyle change scenario trade-offs are somewhat reduced compared to the other scenarios by a lower consumption level (which by itself has mostly synergies), but this hinges on the ability to implement these changes.

\section{Discussion}

In the discussion, we would like to briefly discuss two key issues: 1) the implementation of the different scenarios and 2 ) the role of scenario analysis.

\subsection{Implementation of the different scenarios}

In the analysis we have mostly focused on the measures that can be implemented in addressing sustainable development objectives. We have paid little attention to implementation issues. From the literature, it is possible to identify some of these barriers. In the field of food and biodiversity, the most important barriers include (OECD-FAO, 2011; PBL, 2012; Watson, 2008): 1) persistent low incomes limit access to food, 2) many smallholder farmers have limited opportunities to increase production, 3) low levels of public investment in agricultural research and development, 4) undervaluation (no or low prices) of ecological goods and services, 5) lack of consideration of biodiversity concerns in other policy areas, 
Table 8

Synergies and trade-offs between different objectives (as covered in this study). Colours indicate synergies (green) and trade-offs (red).

\begin{tabular}{|c|c|c|c|c|c|c|c|}
\hline & $\begin{array}{l}\text { Eridicate } \\
\text { hunger }\end{array}$ & $\begin{array}{l}\text { Halting } \\
\text { biodiversity loss }\end{array}$ & $\begin{array}{l}\text { Access to } \\
\text { energy }\end{array}$ & $\begin{array}{l}\text { Reduce air } \\
\text { pollution }\end{array}$ & $\begin{array}{l}\text { Mitigate climate } \\
\text { change }\end{array}$ & $\begin{array}{l}\text { Access to clean } \\
\text { water }\end{array}$ & $\begin{array}{l}\text { Balance } \\
\text { nitrogen cycle }\end{array}$ \\
\hline $\begin{array}{l}\text { Eradicate } \\
\text { hunger }\end{array}$ & & & & & $\begin{array}{l}\text { More emissions } \\
\text { from increased } \\
\text { production } \\
\text { (fertliser, land } \\
\text { expansion, } \\
\text { tractors) }\left(^{*}\right)\end{array}$ & $\begin{array}{l}\text { Increased water } \\
\text { use for } \\
\text { agriculture }\left(^{*}\right)\end{array}$ & $\begin{array}{l}\text { More emissions } \\
\text { from increased } \\
\text { production } \\
(\text { fertliser, manure) } \\
\left({ }^{*}\right)\end{array}$ \\
\hline \multirow[t]{2}{*}{$\begin{array}{l}\text { Halt biodiv. } \\
\text { Loss }\end{array}$} & $\begin{array}{l}\text { Less land for } \\
\text { food production }\left({ }^{*}\right)\end{array}$ & & & $\begin{array}{l}\text { Intact ecosystems } \\
\text { contribute to } \\
\text { better air quality }\end{array}$ & $\begin{array}{l}\text { Fewer } \mathrm{CO}_{2} \\
\text { emissions from } \\
\text { land conversion } \\
\text { and agriculture, }\end{array}$ & $\begin{array}{l}\text { More gradual } \\
\text { and uniform } \\
\text { water flow, } \\
\text { cleaner water }\end{array}$ & \multirow[t]{2}{*}{$\begin{array}{l}\text { More } \\
\text { contribution of } \\
\text { ecosystems in } \\
\text { balancing } \\
\text { nitrogen cycle }\end{array}$} \\
\hline & $\begin{array}{l}\text { Preservation of } \\
\text { ecosystem } \\
\text { services helps } \\
\text { safeguard long- } \\
\text { term food supply }\end{array}$ & & & & new $\mathrm{CO}_{2}$ sinks $\left(^{*}\right)$ & $\begin{array}{l}\text { Increased water } \\
\text { use by } \\
\text { permanent } \\
\text { vegetation }\end{array}$ & \\
\hline $\begin{array}{l}\text { Access to } \\
\text { energy }\end{array}$ & $\begin{array}{l}\text { Increases income } \\
\text { opportunities due } \\
\text { to reduced time } \\
\text { for fuel } \\
\text { collection, better } \\
\text { health. }\end{array}$ & $\begin{array}{l}\text { Less disturbance } \\
\text { of local } \\
\text { biodiversity for } \\
\text { food collection }\end{array}$ & & $\begin{array}{l}\text { Less indoor and } \\
\text { urban air } \\
\text { pollution }\left({ }^{*}\right)\end{array}$ & $\begin{array}{l}\text { New emissions } \\
\text { from modern } \\
\text { energy offset by } \\
\text { reduced } \\
\text { traditional } \\
\text { energy emissions } \\
\left({ }^{*}\right)\end{array}$ & $\begin{array}{l}\text { Water } \\
\text { requirement for } \\
\text { power generation } \\
(\text { small })\left({ }^{*}\right)\end{array}$ & \\
\hline $\begin{array}{l}\text { Reduce air } \\
\text { pollution }\end{array}$ & $\begin{array}{l}\text { Less negative } \\
\text { impact of air } \\
\text { pollution on crop } \\
\text { yields }\end{array}$ & $\begin{array}{l}\text { Less air } \\
\text { pollutions } \\
\text { impacts on } \\
\text { biodiversity }\left({ }^{*}\right)\end{array}$ & $\begin{array}{l}\text { Higher energy } \\
\text { prices }\end{array}$ & & $\begin{array}{l}\text { Depends on } \\
\text { which air } \\
\text { pollutants are } \\
\text { reduced }\left({ }^{*}\right) \text {. }\end{array}$ & $\begin{array}{l}\text { Less water } \\
\text { pollution }\end{array}$ & $\begin{array}{l}\text { Helps to reduce } \\
\text { nitrogen } \\
\text { deposition }\left({ }^{*}\right)\end{array}$ \\
\hline \multirow[t]{2}{*}{$\begin{array}{l}\text { Mitigate clim. } \\
\text { Change }\end{array}$} & $\begin{array}{l}\text { Reduces negative } \\
\text { impacts on yields } \\
\text { (but also positive } \\
\text { impacts) }\left(^{*}\right)\end{array}$ & $\begin{array}{l}\text { Reduces negative } \\
\text { impacts of } \\
\text { climate change } \\
\left({ }^{*}\right)\end{array}$ & \multirow[t]{2}{*}{$\begin{array}{l}\text { Higher energy } \\
\text { prices }\left({ }^{*}\right)\end{array}$} & \multirow[t]{2}{*}{$\begin{array}{l}\text { Less emissions } \\
\text { of air pollutants } \\
\text { due to lower } \\
\text { fossil fuel use }\left(^{*}\right)\end{array}$} & & \multirow[t]{2}{*}{$\begin{array}{l}\text { Negative impacts } \\
\text { on precipitation } \\
\text { patterns and } \\
\text { evapotranspiration } \\
\text { reduced }\left(^{*}\right)\end{array}$} & \multirow[t]{2}{*}{$\begin{array}{l}\text { Some positive } \\
\text { impact } \mathrm{N}_{2} \mathrm{O} \\
\text { emission } \\
\text { reduction }\left({ }^{*}\right)\end{array}$} \\
\hline & $\begin{array}{l}\text { Bio-energy } \\
\text { competes for } \\
\text { land with food } \\
\text { production }\end{array}$ & $\begin{array}{l}\text { Additional land } \\
\text { for bio-energy } \\
\left({ }^{*}\right)\end{array}$ & & & & & \\
\hline \multirow[t]{2}{*}{$\begin{array}{l}\text { Access to clean } \\
\text { water }\end{array}$} & $\begin{array}{l}\text { Improved water } \\
\text { for cooking }\end{array}$ & & & & & & \\
\hline & $\begin{array}{l}\text { Competition } \\
\text { between } \\
\text { agriculture and } \\
\text { domestic } \\
\text { purposes }\end{array}$ & & & & & & \\
\hline $\begin{array}{l}\text { Balance } \\
\text { nitrogen cycle }\end{array}$ & $\begin{array}{l}\text { Reduction of } \\
\text { fertilizer use (but } \\
\text { also prevents } \\
\text { toxic fertilizer } \\
\text { levels) }\end{array}$ & $\begin{array}{l}\text { Reduces } \\
\text { pollution }\end{array}$ & & $\begin{array}{l}\text { Reduces air } \\
\text { pollution }\end{array}$ & $\begin{array}{l}\text { Some reduction } \\
\text { of } \mathrm{N}_{2} \mathrm{O} \text { emissions }\end{array}$ & & \\
\hline
\end{tabular}

Note: * denotes that the linkages is addressed quantitatively by the modelling framework.

6) lack of governance structures to manage natural capital and 7) a lack of information about possible policies and measures. In the field of energy and climate, similar barriers are important, including 1) pervasive doubt about the extent and seriousness of climate change, 2) large and conflicting interests in the energy system (e.g. energy producers versus consumers), 3) lock-in dynamics and subsidizing of fossil fuels, 4) uncertainty regarding energy prices, 5) a bias towards supply-side investments over those on the demand side, 6) a lack of commitment to address the energy needs of the poorest segments of the population and 7) a lack of access to technology. Clearly, in order to implement the Challenge Scenarios, policy instruments will need to be introduced, along with the measures discussed so-far, to address these barriers. But in addition, each scenario will face specific challenges. The Global Technology pathway relies heavily on international cooperation (while at the moment, it seems many international treaties are confronted with strong differences in interest) and technology improvement (e.g. for agricultural yields). The Consumption Change scenario relies heavily on the willingness of different societal groups to participate in the changes towards less resource-intensive consumption patterns (which will face strong resistance, certainly in some regions). Several historical examples are available of successful and failed (intended) lifestyle transitions (e.g. concerning energy efficiency, recycling and smoking behavior), also in relation to government policies to induce or support such transitions (Hajer, 2011; PBL, 2012). Finally, for the Decentralized Solutions scenario, in addition to the technological challenges, also coordination of the responses in different regions will represent a key challenge. Therefore, combining certain elements of these scenarios may be more effective. The additional advantage of such an approach would be that different options appeal to different actors; a broad strategy would do more justice to heterogeneity in society, and would mobilize its energy. Obviously, combinations would have to be coherent, and 
the scope for choosing combinations varies depending on the subject. Further analysis of the policy implications of the different scenarios would be an interesting follow-up.

\subsection{Limitations of the current analysis}

Clearly, the IMAGE model scenarios presented here include a wide range of assumptions and in some cases choices have been made how to interpret specific storylines. In the time frame of the study, it was too complex to add a formal uncertainty analysis - although the differences across the various Challenge Scenarios obviously provide a key illustration of uncertainty. Still, the contribution of individual measures in addressing the different challenges should be mostly seen as explorative. At the most aggregate level, however, conclusions are more robust. In other words, while the contribution of wind power in the Global Technology scenario should be regarded as rather uncertain, the implications for the decarbonisation rate or for overall yield improvement are far more robust. In order to increase the insights in the uncertainties and robust messages it would be interesting to explore these scenarios using a wider set of integrated assessment models - similar to the recent sets of model intercomparison projects for climate policy (e.g. Riahi et al., 2015).

\section{Conclusions}

In this paper, we looked at the possibilities for achieving a set of long-term sustainable development objectives in 2050, which are consistent with current international agreements (e.g. the Millennium Development Goals, UNFCCC and UN CBD). ${ }^{3}$ The paper focused on several key sustainability issues related to the food-energy-water nexus, including the challenges to: 1) eradicate hunger and maintaining a stable and sufficient food production, while conserving biodiversity; and to 2) ensure access to modern energy sources for all, while limiting global climate change and air pollution. In addition, we briefly looked at some related issues (nitrogen, water and health). The analysis focussed on implementing (physical) measures consistent with achieving sustainable development objectives, based on three alternative approaches. The scenarios are meant to be mostly explorative, and are based on a back casting approach using the integrated assessment model IMAGE. The scenarios that achieve these objectives can be used to derive more short-term actions. We have not explicitly addressed the question how these policies can be implemented (although the three storylines of the alternative scenarios do relate to this). Based on the analysis, the following key conclusions can be drawn.

Without additional policies, the nexus-related sustainable development objectives in 2050 will not be achieved, despite progress for human development related issues. For the Trend scenario (i.e. assuming no new sustainability policies), model calculations suggest that the situation worsens with respect to environmental objectives. Greenhouse gas emissions are projected to double between 2010 and 2050, while the target is a $50 \%$ reduction. Furthermore, global biodiversity continues to decline with the historic rate. With respect to human

\footnotetext{
${ }^{3}$ As the SDGs have not yet been agreed upon, the set of objectives analyzed here could be considered as SDGs avant la lettre.
}

development some progress is projected driven by strong economic development in Sub-Saharan Africa and South Asia, but progress is expected to fall short of the development objectives of eradicating hunger and providing full access to modern sources of energy in 2050.

In this paper, three alternative scenarios have been formulated. The scenarios show that marginal improvements will not suffice to meet a set of sustainable development objectives in 2050: instead, large, transformative changes are needed to realize these objectives. The alternative Challenge Scenarios explore different combinations of technological measures and consumption changes in order to achieve the set of sustainability objectives. Clearly, in each scenario specific problems will have to be overcome, such as the environmental impacts of intensive agriculture (Global technology scenario) or the difficulty of influencing consumption patterns (Consumption change scenario). The analysis shows that although in the scenarios the environmental and development objectives could be achieved, this would require rather bold, systemic changes.

Decoupling of $\mathrm{CO}_{2}$ emissions from economic growth needs to take place at $4 \%$ to $6 \%$ a year, over the next decades, to meet the climate target of a $2{ }^{\circ} \mathrm{C}$ maximum temperature increase by 2100 . This is to be compared to the historical rate of $1 \%$ to $2 \%$. This requires a fundamental transition in the energy system. In agriculture, an average productivity increase of around $1 \%$ a year would be needed to provide sufficient food for all, while limiting biodiversity loss. This rate is comparable to historical improvement rates, but might be more difficult to achieve in the future, as yields get closer to maximum achievable yields. Some measures play a major role in all scenarios such as energy efficiency improvement, considerable improvement of agricultural yields and a strong shift towards renewable energy and carbon-capture-and-storage. Although not all combinations are possible, combining elements of the pathways could make the response strategy more robust. This would also do justice to the pluriformity in society as different elements are appealing to different actors in different regions.

There is no fundamental trade-off between eradicating hunger as well as providing full access to modern energy, on the one hand, and achieving environmental sustainability, on the other. Eradicating hunger and providing access to modern energy for all (beyond production increases that result from population and economic growth) does not have to negatively affect global biodiversity or climate change in a substantial way. Even if access to modern fuels for cooking and heating for the poor is achieved with fossil-fuel-based products, this would result in only a small increase in $\mathrm{CO}_{2}$ emissions, (partly) compensated by reducing emissions from deforestation and of black carbon. Furthermore, the additional increase in food production required to eradicate hunger would also be only a fraction of required future production levels. If hunger eradication would be facilitated by a redistribution of current consumption levels, the required increase in production would be even less. Obviously further development beyond "basic levels" will coincide with much more important trade-offs. Also here, this studies suggests that these trade-offs can be addressed if effective policies are implemented.

Resolving the key-challenges related to the energy-land-water nexus requires a broad set of measures to be implemented. In order to feed a growing and overall wealthier population, food production needs to increase by around 60\% in the 2010-2050 
period. Substantial effort is needed on multiple fronts to meet sustainable development objectives, including improved yields (especially in areas with relatively low yields compared to their potential), waste reduction, climate change mitigation, better land management policies and the expansion of protected areas. Lifestyle changes towards less resource-intensive consumption patterns may also contribute significantly to the achievement of these targets. As is the case for food, energy production also is expected to increase by around $60 \%$ over the next four decades. At the same time, greenhouse gas emissions would need to be halved in order to achieve the $2{ }^{\circ} \mathrm{C}$ target to limit climate change. Further electrification in the transport and household sectors could ensure more flexibility in reducing emissions. On the supply side, by 2050 , around $60 \%$ of all energy would need to come from non- $\mathrm{CO}_{2}$ emitting energy sources, such as renewables, bio-energy, nuclear power, and fossil fuel combined with $\mathrm{CO}_{2}$ capture (the current share of these technologies is $20 \%$ ). Reducing non- $\mathrm{CO}_{2}$ greenhouse gas emissions is also part of an effective strategy, because of low costs and co-benefits, although the long-term mitigating potential is limited.

Studies like the one presented here can help exploring strategies to meet the Sustainable Development Goals (SDGs). Clearly, this study is not the first to emphasize the existing opportunities for a change towards a more sustainable development. Still, there seems to be a large gap between the formulation of a long-term ambition and the current, short-term policies implemented by policy-makers. It has to be concluded that the approaches used to unlock this potential of achieving the internationally agreed ambition, so far, has not been very successful. Although it is hard to ex-ante evaluate the effectiveness of alternative scenarios, the analysis provided in this article could potentially contribute to implementing the SDGs as well as a shared vision of long-term objectives and consistent short-term targets, integrating various areas of sustainable development. By exploring pathways towards meeting long term objectives and targets, an integrated perspective across both the desired end objectives and how to get there can be established, including intervention strategies, interim steps and targets over time.

\section{Acknowledgements}

This article benefited from funding from the European Union Seventh Framework Programme (FP7/2007-2013) under grant agreement $n^{\circ} 603942$ (PATHWAYS).

\section{References}

AGECC, 2010. nergy for a sustainable future. Summary report and recommendations. The secretary-general's Advisory group on Energy and climate Change, New York.

Alkemade, R., Van Oorschot, M., Miles, L., Nellemann, C., Bakkenes, M., ten Brink B., 2009. GLOBIO3: A Framework to investigate options for reducing global terrestrial biodiversity loss. Ecosystems 12, 374-390.

Arnell, N.W., Van Vuuren, D.P., Isaac, M., 2011. The implications of climate policy for the impacts of climate change on global water resources. Glob. Environ. Chang. 21, 592-603.

Bennett, E.M., Balvanera, P., 2007. The future of production systems in a globalized world. Front. Ecol. Environ. 5, 191-198.

Bernstein, S., 2013. Rio + 20: Sustainable Development in a Time of Multilateral Decline. Glob. Environ. Polit. 13.
Bouwman, L., Kram, T., Klein-Goldewijk, K., 2006. Integrated modelling of global environmental change. An overview of IMAGE 2.4. Netherlands Environmental Assessment Agency, Bilthoven.

Bouwman, A.F., Beusen, A.H.W., Billen, G., 2009. Human alteration of the global nitrogen and phosphorus soil balances for the period 1970-2050. Glob. Biogeochem. Cycles 23.

Brussaard, L., Caron, P., Campbell, B., Lipper, L., Mainka, S., Rabbinge, R., Babin, D., Pulleman, M., 2010. Reconciling biodiversity conservation and food security: Scientific challenges for a new agriculture. Curr. Opin. Environ. Sustain. 2, 34-42.

CBD, 2010. COP 10 Decision X/2: Strategic Plan for Biodiversity 2011-2020. Secretariat of the Convention on Biological Diversity, Nagoya, Japan.

Chuwah, C., van Noije, T., van Vuuren, D.P., Hazeleger, W., Strunk, A., Deetman, S., Beltran, A.M., van Vliet, J., 2013. Implications of alternative assumptions regarding future air pollution control in scenarios similar to the Representative Concentration Pathways. Atmos. Environ. 79, 787-801.

Clarke, L., Edmonds, J., Krey, V., Richels, R., Rose, S., Tavoni, M., 2010. International Climate Policy Architectures: Overview of the EMF 22 International Scenarios. Energy Econ. 31 (Suppl. 2), S64-S81.

Daioglou, V., van Ruijven, B.J., van Vuuren, D.P., 2012. Model projections for household energy use in developing countries. Energy 37, 601-615.

Edenhofer, O., Knopf, B., Barker, T., Baumstark, L., Bellevrat, E., Chateau, B., Criqui, P., Isaac, M., Kitous, A., Kypreos, S., Leimbach, M., Lessmann, K., Magné, B., Scrieciu, S., Turton, H., Van Vuuren, D.P., 2010. The economics of low stabilization: Model comparison of mitigation strategies and costs. Energy J. 31, 11-48.

Evans, A., Steven, D., 2012. Sustainable Development Goals-A Useful Outcome From Rio +20 . New York University Center of International Cooperation, New York.

FAO, 2006. World agriculture: towards 2030/2050. Interim report: Prospects for food, nutrition, agriculture and major commodity groups. Global Perspective Studies Unit, Food and Agriculture Organization of the United Nations, Rome, p. 71.

GEA, 2012. The Global Energy Assessment: Toward a More Sustainable Future. Cambridge University Press, Cambridge and IIASA, Laxenburg.

GEGP, 2012. Rio + 20 Responses.

Godfray, H.C.J., Beddington, J.R., Crute, I.R., Haddad, L., Lawrence, D., Muir, J.F., Pretty, J., Robinson, S., Thomas, S.M., Toulmin, C., 2010. Food Security: The Challenge of Feeding 9 Billion People. Science 327, 812-818.

Hajer, M., 2011. The energetic society. In search of a governance philosophy for a clean economy. PBL Netherlands Environmental Assessment Agency, Bilthoven.

Hanrahan, 2012. Rio + 20 in review.

Hilderink, H.B.M., Lucas, P.L. (Eds.), 2008. Towards a Global Integrated Sustainability Model: GISMO 1.0 status report. Netherlands Environmental Assessment Agency (PBL), Bilthoven, the Netherlands.

Hutton, G., Rehfuess, E., Tediosi, F., Weiss, S., 2006. Evaluation of the costs and benefits of household energy and health interventions at global and regional levels. World Health Organisation, Geneva.

IMECHE, 2012. Global food. Waste not. Want not. Institution of Mechanical Engineers.

Ivanova, I., 2013. The Contested Legacy of Rio + 20. Glob. Environ. Polit. 13.

Klein, N., 2013. How science is telling us all to revolt NewStatesman October 29.

Lambin, E.F., Meyfroidt, P., 2011. Global land use change, economic globalization, and the looming land scarcity. PNAS 108, 3465-3472.

Lucas, P.L., van Vuuren, D.P., Olivier, J.G.J., den Elzen, M.G.J., 2007. Long-term reduction potential of non-CO2 greenhouse gases. Environ. Sci. Policy 10, 85-103.

Lucas, P.L., Kok, M.T.J., Nilsson, M., Alkemade, R., 2014. Integrating Biodiversity and Ecosystem Services in the Post-2015 Development Agenda: Goal Structure, Target Areas and Means of Implementation. Sustainability 6, 193-216.

MA, 2005. Millennium Ecosystem Assessment Synthesis Report. Island Press, Washington DC

Nilsson, M., Lucas, P., Yoshiba, T., 2013. Towards an Integrated Framework for SDGs: Ultimate and Enabling Goals for the Case of Energy. Sustainability 5, 4124-4151.

OECD, 2012. OECD Environmental Outlook to 2030. Organisation for Economic Co-operation and Development, Paris.

OECD-FAO, 2011. Agricultural Outlook 2011-2020. Organisation for Economic Co-operation and Development, Food and Agriculture Organization of the United Nations.

Ozkaynak, B., Pinter, L., van Vuuren, D.P., 2012. Scenarios and Sustainability Transformation. In: UNEP (Ed.), Global Environment Outlook 5. Progress Press Ltd, Malta.

Pachauri, S., Van Ruijven, B.J., Nagai, Y., Riahi, K., Van Vuuren, D.P., BrewHammond, A., Nakicenovic, N., 2013. Pathways to achieve universal household access to modern energy by 2030. Environ. Res. Lett. 8.

Patt, A.G., van Vuuren, D.P., Berkhout, F., Aaheim, A., Hof, A.F., Isaac, M., Mechler, R., 2010. Adaptation in integrated assessment modeling: where do we stand? Clim. Chang. 99, 383-402. 
PBL (Ed.), 2012. Roads from Rio + 20 Pathways to achieve global sustainability goals by 2050. PBL Netherlands Environmental Assessment Agency, Bilthoven, The Netherlands.

Rabbinge, R., Bindraban, P.S., 2012. Making More Food Available: Promoting Sustainable Agricultural Production. Agric. Sci. China 11, 1-8.

Riahi, K., Dentener, F., Gielen, D., Grubler, A., Jewell, J., Klimont, Z., Krey, V., McCollum, D., Pachauri, S., Rao, S., van Ruijven, B.J., van Vuuren, D.P., Wilson, C., 2012. Energy Pathways for Sustainable Development. In: GEA (Ed.), The Global Energy Assessment: Toward a More Sustainable Future. Cambridge University Press, Cambridge, UK and IIASA, Laxenburg.

Riahi, K., Kriegler, E., Johnson, N., Bertram, C., den Elzen, M., Eom, J., Schaeffer, M., Edmonds, J., Isaac, M., Krey, V., Longden, T., Luderer, G., Méjean, A., McCollum, D.L., Mima, S., Turton, H., van Vuuren, D.P., Wada, K., Bosetti, V., Capros, P., Criqui, P., Hamdi-Cherif, M., Kainuma, M., Edenhofer, O., 2015. Locked into Copenhagen pledges - Implications of short-term emission targets for the cost and feasibility of long-term climate goals. Technol. Forecast. Soc. Chang. 90, 8-23.

Rockström, J., Steffen, W., Noone, K., Persson, Ã., Chapin, F.S., Lambin, E.F., Lenton, T.M., Scheffer, M., Folke, C., Schellnhuber, H.J., Nykvist, B., De Wit, C.A., Hughes, T., Van Der Leeuw, S., Rodhe, H., SÃ frlin, S., Snyder, P.K., Costanza, R., Svedin, U., Falkenmark, M., Karlberg, L., Corell, R.W., Fabry, V.J., Hansen, J., Walker, B., Liverman, D., Richardson, K., Crutzen, P., Foley, J.A., 2009. A safe operating space for humanity. Nature 461, 472-475.

Smith, P., Gregory, P.J., Van Vuuren, D., Obersteiner, M., Havlík, P., Rounsevell, M., Woods, J., Stehfest, E., Bellarby, J., 2010. Competition for land. Philos. Trans. R. Soc. B 365, 2941-2957.

Smith, K., Balakrishnan, K., Butler, C.D., Chafe, Z., Fairlie, I., Kinney, P., Kjellstrom, T., Mauzerall, D.L., McKone, T., McMichael, A., Schneider, M., Wilkinson, P., 2012. Energy and health. In: GEA (Ed.), The Global Energy Assessment: Toward a More Sustainable Future. Cambridge University Press, Cambridge, UK and IIASA, Laxenburg.

Steffen, W., Richardson, K., Rockström, J., Cornell, S.E., Fetzer, I., Bennett, E.M., Biggs, R., Carpenter, S.R., de Vries, W., de Wit, C.A., Folke, C., Gerten, D., Heinke, J., Mace, G.M., Persson, L.M., Ramanathan, V., Reyers, B., Sörlin, S., 2015. Planetary boundaries: Guiding human development on a changing planet. Science. http://dx.doi.org/10.1126/science.1259855.

Stehfest, E., Bouwman, L., van Vuuren, D., den Elzen, M., Eickhout, B., Kabat, P., 2009. Climate benefits of changing diet. Clim. Chang. 95, 83-102.

UN, 2000. United Nations Millennium Declaration. Resolution adopted by the General Assembly. United Nations, New York.

UN, 2008. World Population Prospects: The 2008 Revision. Population Division of the Department of Economic and Social Affairs of the United Nations Secretariat, New York

UN, 2012. The future we want. Outcome of the conference. Rio +20 United Nations Conference on Sustainable Development. Rio de Janeiro, Brazil.

UNCED, 1992. United Nations Conference on Environment and Development. A.CONF.15/5/Rev.1. Rio de Janeiro, Brazil.

UNEP, 2012. Global Environmental Outlook 2012. Ubited Nations Environmental Programme.

UNFCCC, 1992. United Nations Framework Convention on Climate Change. http://www.unfccc.int/resources.

UNFCCC, 2010. Report of the Conference of the Parties on its sixteenth session, held in Cancun from 29 November to 10 December 2010. Addendum. Part Two: Action taken by the Conference of the Parties at its sixteenth session. Decision 1/CP.16: The Cancun Agreements: Outcome of the work of the Ad Hoc Working Group on Long-term Cooperative Action under the Convention FCCC/CP/2010/7/Add.12010.

van den Berg, M., Bakkes, J.A., Bouwman, L., Jeuken, M., Kram, T., Neumann, K., van Vuuren, D.P., Wilting, H., 2011. EU Resource Efficiency perspectieven op wereldschaal. PBL Netherlands Environmental Assessment Agency.

Van Ruijven, B., Schers, J., Van Vuuren, D.P., 2012. A global model for rural electrification in developing countries. Energy Policy 38 (1), 386-397.

van Vuuren, D.P., Stehfest, E., 2013. If climate action becomes urgent: the importance of response times for various climate strategies. Clim. Chang. $121,473-486$

van Vuuren, D.P., Den Elzen, M.G.J., Lucas, P.L., Eickhout, B., Strengers, B.J., Van Ruijven, B., Wonink, S., Van Houdt, R., 2007. Stabilizing greenhouse gas concentrations at low levels: An assessment of reduction strategies and costs. Clim. Chang. 81, 119-159.

van Vuuren, D.P., Stehfest, E., den Elzen, M.G.J., Kram, T., van Vliet, J., Deetman, S., Isaac, M., Goldewijk, K.K., Hof, A., Beltran, A.M., Oostenrijk, R., van Ruijven, B., 2011. RCP2.6: Exploring the possibility to keep global mean temperature increase below $2{ }^{\circ} \mathrm{C}$. Clim. Chang. 109, 95-116.

van Vuuren, D.P., Kok, M.T.J., Girod, B., Lucas, P.L., de Vries, B., 2012a. Scenarios in Global Environmental Assessments: Key characteristics and lessons for future use. Glob. Environ. Chang. 22, 884-895.

van Vuuren, D.P., Nakicenovic, N., Riahi, K., Brew-Hammond, A., Kammen, D., Modi, V., Nilsson, M., Smith, K.R., 2012b. An energy vision: The transformation towards sustainability-interconnected challenges and solutions. Curr. Opin. Environ. Sustain. 4, 18-34.
Watson, B. (Ed.), 2008. International Assessment of Agricultural Science and Technology Development.

WHO, 2005. Air Quality Guidelines: Global Update for 2005. http://www. euro.who.int/Document/E87950.pdf. WHO Regional Office for Europe, Copenhagen, Denmark.

Detlef van Vuuren is professor of integrated assessment of global environmental change at Utrecht University and senior researcher at PBL Netherlands Environmental Assessment Agency. His work concentrates on scenario analysis of response strategies to global environmental change issues. Detlef van Vuuren has published over 180 peer-reviewed articles and has been an author on a large number of integrated assessment reports.

Marcel Kok is programme leader Environment and Development and senior researcher at PBL Netherlands Environmental Assessment Agency. His research concentrates on global environmental governance strategies and scenario analysis of global environmental problems, most recent in particular on mainstreaming biodiversity, bottom up approaches to global governance, sustainable supply chains and vulnerability analysis.

Paul Lucas is a policy researcher and integrated assessment modeler working at PBL Netherlands Environmental Assessment Agency. His work focusses on reconciling mitigating global environmental change with achieving human development, including the role of the Sustainable Development Goals. He has published in a number of peer-reviewed journals and has been involved in various international environmental assessments and reports.

Anne Gerdien Prins is a researcher at PBL Netherlands Environmental Assessment Agency working on sustainable issues, mostly in relation to global land use issues. In this function, she has published several reports on global food and biomass issues and the relation with biodiversity.

Rob Alkemade is senior researcher at PBL Netherlands Environmental Assessment Agency and visiting scientist at Environmental Systems Analysis Group of Wageningen University. He works on global modelling of biodiversity and ecosystem services in relation to environmental changes and is author of a series of global integrated assessment reports and peer reviewed articles.

Maurits van den Berg's work focusses on agricultural production systems and their interrelationships with food supply and environmental change at multiple spatial and temporal scales. He worked until 2013 at the PBL and since then at the Institute for Environment and Sustainability of the Joint Research Centre (JRC) of the European Commission.

Lex Bouwman is a professor at Utrecht University and a senior researcher at PBL Netherlands Environmental Assessment Agency. His work concentrates at modelling of nutrient transport from land to sea, biogeochemistry in rivers and impacts of changing nutrient loads in coastal seas.

Stefan van der Esch works as economist for the department of Nature and Rural Areas at PBL Netherlands Environmental Assessment Agency. His work focuses on the interactions between land use, food and biodiversity, on natural capital accounting and reporting, and on policy instruments for sustainable use of biodiversity.

Michel Jeuken is a scientific software engineer at Deltares. Previously, he worked at PBL Netherlands Environmental Assessment Agency on modelling biodiversity using PBL's GLOBIO and quantification of biodiversity indicators in an international context.

Tom Kram works at PBL Netherlands Environmental Assessment Agency as project leader of the IMAGE project. He is also one of the co-chairs of the International Committee On New Integrated Climate change assessment Scenarios (ICONICS) and forms part of the scientific steering committee of the Integrated Assessment Modeling Consortium (IAMC).

Elke Stehfest is a scientist at PBL Netherlands Environmental Assessment Agency since 2006. She has worked on a wide range of land-related topics in global integrated assessment, like crop modeling, land-use dynamics, emissions from land use and land-use change, land-based mitigation options, biofuels, and dietary changes. She coordinates the development of the land part of PBL's integrated assessment model IMAGE. 